\title{
Application of Cellulosic Fiber in Soil Erosion Mitigation: Prospect and Challenges
}

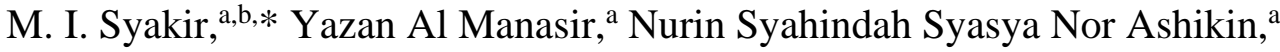 \\ Shaiful Yusuff, ${ }^{a}$ Mark Zuknik, ${ }^{\text {a }}$ and H. P. S. Abdul Khalil ${ }^{\text {a }}$ \\ The agricultural industry is one of the main economic contributors in \\ developing countries, especially in tropical regions. Extensive land \\ clearing has led to severe erosion within the watersheds, which increases \\ the vulnerability of water catchments to natural disasters, such as floods. \\ Cellulosic fibers, such as jute, sisal, kenaf, hemp, and coir, are gaining \\ increasing worldwide attention for their potential application in controlling \\ soil erosion, principally due to their remarkable biodegradable and \\ physical properties. Nonetheless, the research on biocomposites in \\ controlling soil erosion is limited compared to the natural fibers. This is \\ perhaps due to poor availability and high cost of biodegradable polymers \\ compared to natural fibers, which are abundant and inexpensive. Poor \\ adhesive interactions between the matrix and natural fibers due to the \\ hydrophilic characteristic of the fibers is another major drawback that limits \\ the development of biocomposites for controlling soil erosion.
}

Keywords: Cellulosic fiber; Biomass wastes; Soil stabilizer; biocomposite; Environment; Sustainable

Contact information: a: School of Industrial Technology, Universiti Sains Malaysia, Penang, Malaysia 11800; b: Centre for Global Sustainability Studies (CGSS), Universiti Sains Malaysia, Penang, Malaysia 11800; *Corresponding author: misyakir@usm.my

\section{INTRODUCTION}

Awareness of the potential replacement of synthetic polymers with biodegradable sources first arose in the late 1970s. This was due to the oil crisis that occurred during that era and the difficulties in composting synthetic polymers relative to natural polymers (Hatakeyama et al. 1977). The proliferation of synthetic polymers and the extensive dumping of such waste into the ocean and landfills have led to various environmental problems, such as the ingestion of plastic materials by wildlife in the ocean and land that ultimately causes fatalities (Huang et al. 1990). The United States became the world's top leader for environmental innovation in the late 1960s, whereas environmental interest and action in Europe began only during the 1980s (Lampe and Gazda 1995). In Asia, Japanese researchers began to replace synthetic plastic with fermented carbohydrate polymers in the 1970's (Glass) (John et al. 1998). Since then, various studies and research have been conducted globally to fully utilize natural resources and recycled waste materials to replace petroleum-based non-biodegradable polymers.

The evolution of natural fiber as a reinforcement material in biodegradable composites has been growing tremendously in industrial and research fields. Natural fiber is a fiber that originates from any natural resource, which includes plants and animals (Ticoalu et al. 2010). Natural fibers have good mechanical properties, especially when compared to synthetic fibers (May-Pat et al. 2013). Natural fibers, particularly from plants, such as sisal, hemp, flax, bamboo, coconut, kenaf, jute, and ramie (Ticoalu et al. 2010), are 
relatively low density, low weight, low cost, energy-efficient, non-toxic, renewable, recyclable, and biodegradable (Herrmann et al. 1998; Wambua et al. 2003; Cheung et al. 2009; Thomas and Pothan 2009). Therefore, natural fibers are both environmentally friendly and cost-effective.

Natural fibers have been innovatively embedded with biopolymer matrices made up of cellulose, starch, and lactic acid to form biocomposites since the 1980s (Herrmann et al. 1998). The biopolymer matrix in a biocomposite functions to stabilize the shape of the structure, transfer the pressure between the fibers, and functions as a coating to protect the composite from damage (Moser 1992; Luo and Netravali 1999). Formerly, biocomposites have been used in packaging and agricultural industries (Herrmann et al. 1998). However, due to growing demand, they have also been used in the automotive industry. Due to their equivalent cost with glass fiber-reinforced plastics, biocomposites have also been applied in the building industry as door panels, as they offer aesthetic value and are resistant to scratching and ultraviolet degradation (Marsh 2003).

Today natural fiber has gained attention from various industries due to its abundance availability and good mechanical properties. The scope of this manuscript is to discuss the natural fiber derived from agricultural byproducts and its potential applications as soil cover for erosion mitigation. Various strategies have been implemented to stabilize soil structure, including mechanical, physical, and chemical reaction techniques. Soil reinforcement, soil replacement, compaction, and chemical soil stabilization are some of the techniques to enhance the mechanical properties of soil (Tabatabaee 1985). In review, the efficiency of controlling soil erosion by using natural resources, such as EFB, oil palm frond, eco-mat, and leguminous cover crop plants, are discussed. However, cellulosic-soil mixing strategies are outside of the scope of this manuscript. As well, this review aimed to study the current trends in the applications of biodegradable materials and biocomposites in soil erosion mitigation.

The agricultural industry is one of the main economic contributors to developing countries, such as Malaysia and Indonesia. Malaysia and Indonesia are among the biggest producers of oil palm in the world, with 5.64 million hectares (Malaysian Palm Oil Council, 2015) and 8 million hectares (Indonesia Investments 2016) of plantation area, respectively. Furthermore, these numbers are projected to increase annually. However, in Malaysia, annual flood events have become more severe, particularly in the East Coast of Peninsular Malaysia. Agricultural activities, such as deforestation and the replanting season of palm oil, have been suspected to be main contributors to these flood events (Zafirah et al. 2016).

Although the increasing exploitation of oil palm brings many advantages to nations engaged in oil palm cultivation, especially economic advantages, environmental impacts must be considered. During the critical stage of oil palm establishment, the exposed surface soil is most vulnerable to erosion, particularly during the rainy season. Soil erosion is one form of soil degradation and is mainly driven by water and wind factors. Although soil erosion is a natural process, anthropogenic activities can increase rates of erosion up to $40 \%$. Soil erosion leads to surface runoff due to the impact of rainfall. Water runoff transports eroded soil into river basins, which eventually causes sedimentation. In addition to deteriorating water quality and aquatic ecosystems, sedimentation also causes shallowing of water bodies until they can no longer sustain any water loads, which leads to overflow of the water bodies and consequent flood disasters.

Therefore, as soil erosion is a worldwide issue, researchers have studied various initiatives to prevent soil erosion from worsening for several decades (Leknoi and Likitlersuang 2020). Research has been carried out is the application of materials, 
particularly natural fibers, through various methods, such as mulching, spraying, coating, and matting methods. Borst and Medersk (1957) used manure and straw mulching to increase the infiltration rate of water into soil. In a more recent study, Deshmukh et al. (2015) used rice straw blankets to promote vegetation growth and increase soil moisture content. However, the cellulosic material application on soil not only can mitigate the soil erosion, but it can also play important role in pest management if applied systematically (Jabran 2019).

\section{CELLULOSIC FIBER FOR SOIL EROSION CONTROL}

The zero burning policy currently employed in many types of plantations is a good example of the development of more sustainable agricultural practices. Therefore, mulching and matting with natural fibers are used in the agricultural industry to control erosion and promote vegetation growth in a wide variety of situations, such as plantations or construction sites (Likitlersuang et al. 2020). In general, attributes of natural fibers such as strength, length, biodegradability, stiffness, size, and weight play important role for the effectiveness of natural fiber application in soil erosion.

In general, attributes of natural fibers such as strength, length, biodegradability, stiffness, size, and weight play important roles for the effectiveness of natural fiber application in soil erosion. Today most of natural fibers applied on soils are in the form of geotextile, i.e. kenaf, sisal, hemp, and bagasse. Others like jute, oil palm empty fruit bunch (OPEFB), wood fiber, and straw are applied directly (Clark 2010). These approaches are employed because they are cost-effective, provide a nutrient supply, and increase the organic matter content in soil with minimal usage of fertilizers and pesticides. The strength and weaknesses of cellulosic fibers used to control soil erosion, i.e. jute, kenaf, oil palm empty fruit bunch, hemp, coir, wood, and straw, are compared and summarized in Table 1.

\section{Jute Fiber}

Jute is a natural fiber that is long, shiny, and golden in color, and it iscommercially obtained from two species, which are the white jute plant (Corchorus capsularis) and the tossa jute plant (C. olitorius). Jute fibers, which are mainly comprised of cellulose and lignin, are extracted via a natural microbial process known as retting (Gupta et al. 1976; Majumdar and Day 1977). Retting is an important process, as the quality of the jute fibers is largely dependent on retting efficiency (Chi et al. 1966; Ahmed and Akhter 2001). Retting involves the immersion of jute bundles in slow running water, such as a channel, streamlet, tank, lake, or reservoir, for $14 \mathrm{~d}$ to $28 \mathrm{~d}$ to break down the pectin materials, hemicellulose, and lignin (Banik et al. 2003; Paridah et al. 2011). However, as the retting process causes environmental pollution and heavy competition in the fiber market, innovative methods have been introduced to enhance final product quality, reduce labor needs, and decrease the costs (Jahan et al. 2016) of jute production.

The Bangladesh Government has recommended a ribbon retting method that improves fiber quality (Banik et al. 2003), requires half the amount of water needed in conventional retting, shortens production time by $4 \mathrm{~d}$ to $5 \mathrm{~d}$, and reduces environmental pollution (Alam 1998). The production of jute is mainly concentrated in India, China, and Bangladesh. Jute fiber is in high demand due to its availability, durability, biodegradability, low thermal conductivity, and fiber uniformity. In India, jute has been traditionally used for packaging materials, such as strings, hessian, carpet backing, gunny bags, and canvas. 
Jute is used globally in diverse industries, which include the automobile, construction, transportation, furniture, textile, and cosmetic industries (Gon et al. 2012; Jirawattanasomkul et al. 2019)

In addition, jute fiber is used in the agricultural industry for land restorationduring the process of natural vegetation establishment. The fiber is applied alone or blended with other polymers (both natural and synthetic). Jute geotextile is used for various civil engineering applications, such as controlling topsoil erosion, protecting river and canal banks, stabilizing slopes, and strengthening road pavements (Jadvani and Gandhi 2013). A case study in India found that, when compared with synthetic erosion control materials, jute geotextiles increased vegetative cover $80 \%$, retained soil nutrients and soil moisture, and reduced maximum dry density (Barooah and Goswami 1997; Datta 2007; Mathur et al. 2008; Jual and Sharda 2008; Aggarwal and Sharma 2010; Islam et al. 2013; Sonthwal and Sahni 2015). This was due to the capacity of jute geotextiles to retain $375 \%$ more water than their dry weight (Islam 2013), which increased the shear strength of the soil (Zaidi et al. 2016) where the root system of plants anchored the soil together, which decreased soil erosion. Jute geotextiles have also been reported to foster vegetation growth due to their outstanding hydrophilic property of absorbing 4.5 times to 6 times more water more than their dry weight (Rickson and Loveday 1998). Due to their various characteristics, jute geotextiles can fully stabilize a slope in only 1 y (Choudhury and Sanyal 2010). Jute net absorbs raindrop impacts and kinetic energy, which reduces surface runoff and its erosion potential (Ingold and Thomson 1990; Mathur et al. 2008) and adds nutrients to the soil upon its decomposition (Mathur et al. 2008).

\section{Kenaf Fiber}

Kenaf or roselle (Hibiscus cannabinus), which is widely commercialized in the southern United States (Kugler 1996; Webber, III et al. 2002) is also known as Java jute, due to its similarity with jute fibers (Feng et al. 2001). Kenaf is comprised of cellulose (the main reinforcing element), lignin, and hemicellulose, which are the binding elements (Feng et al. 2001). Kenaf is a popular cellulosic source that has economic and ecological benefits (Nishino et al. 2003). It is a biennial herbaceous plant that takes 2 y to complete its biological lifecycle. Kenaf can grow under a wide range of weather conditions and can reach a height over $3 \mathrm{~m}$ three months after sowing the seeds (Terry and Reichert 1999). In South Africa, the United States, and Malaysia, kenaf is typically cultivated for its fiber, which is traditionally used to manufacture ropes and sacks.

Kenaf is unique because the stem produces two types of fiber, including coarser fibers (bast fiber) and finer fibers (core fiber), which are located in the outer layer and inner layer, respectively. Bast fiber comprises $35 \%$ of the kenaf plant, and the rest of the plant is comprised of core fiber (Sellers et al. 1993). The properties of kenaf fiber are dependent on the sources, age, separating technique, and history of the fibers (Akil et al. 2011). In addition to its other uses, kenaf fiber is used as an alternative raw material to manufacture paper (Akil et al. 2011), non-woven mats in automotive industries (Magurno 1999), textiles (Ramaswamy et al. 1995), and mats for grass seeding and erosion control (Kaldor et al. 1990; Ramaswamy and Easter 1997; Webber, III et al. 2002).

The kenaf plant has the potential to reduce soil erosion due to its dense and deep root system that holds soil particles together (Lauriault and Puppala 2009). In 1994 and 1995, the United States Department of Agriculture (USDA) spent approximately $\$ 100,000$ to study the structural composite of kenaf fiber and its application in controlling soil erosion (Kugler 1996). The low water absorption characteristics and good mechanical 
properties of kenaf fiber make it a good candidate for soil reinforcement (Artidteang et al. 2012). Artidteang et al. (2012) studied the impact of kenaf geotextile's waving patterns on soil reinforcement applications, and the results demonstrated that the plain pattern of woven kenaf has the highest tensile strength, followed by hexagonal and knot-plain patterns.

\section{Oil Palm Empty Fruit Bunch (OPEFB) Fiber}

The oil palm (Elaeis guineensis) tree, which is commonly used in commercial agriculture to produce palm oil, has a life-span of $25 \mathrm{y}$ to $30 \mathrm{y}$ and can grow up to $20 \mathrm{~m}$ in height. It is cultivated, produced, and commercialized worldwide but mostly by Malaysia and Indonesia, which together account for approximately $85 \%$ of global palm oil production (Indonesia Investment 2016). An oil palm tree consists of approximately $90 \%$ biomass waste and $10 \%$ oil. Every year, billions of tonnes of waste products, particularly OPEFB and palm oil mill effluent (POME), are produced after the sterilization and stripping process of fresh fruit bunches (FFBs) (Abdullah and Sulaiman 2013). For every ton of crude palm oil (CPO) produced, 1.1 tons of OPEFB is disposed of (Karina et al. 2008) due to the difficulty of managing these wastes (Abdullah and Sulaiman 2013).

This abundant major byproduct is sometimes disposed of via incineration, which causes extensive air pollution. Oil palm empty fruit bunch, which is primarily comprised of cellulose, hemicellulose, and lignin (with cellulose contributing the highest percentage of biomass of $49 \%$ to $65 \%$ ), offers the best prospects to be an effective reinforcement material in composites (Rozman et al. 2000; Sreekala et al. 2004; Norul Izani et al. 2013). Many studies have been conducted to sustainably utilize biomass wastes from the oil palm industry. Among these studies, the use of OPEFB in the pulp and paper industry to replace the existing paper from wood sources was explored (Ibrahim 2003; Tanaka et al. 2004).

Studies have also been carried out on the application of OPEFB as a raw material for the production of various materials, such as super capacitor electrodes (Farma et al. 2013), glucose, and xylose (Lim et al. 1997; Rahman et al. 2006), activated carbon (Alam et al. 2007), bio-diesel (Feng 2013), bioethanol (Sudiyani et al. 2013; Chiesa and Gnansounou 2014), and microbial oil (Ahmad et al. 2016). Conventionally, EFB is used as mulching material. Empty fruit branch can also be incinerated to obtain oil palm ash (OPA), which has a high potassium content (Thambirajah et al. 1995; Husin et al. 2002; Farma et al. 2013) and can be applied as soil conditioner and organic fertilizer in estates and plantations. When applied as a soil conditioner, EFB increases the soil's $\mathrm{pH}$, cation exchange capacity, soil moisture, organic carbon, and nutrient contents (Teh et al. 2010; Comte et al. 2013; Frazão et al. 2014), and can thus function as a replacement for chemical nitrogen fertilizers, which tend to increase the acidity of the soil in oil palm plantations due to the removal of base cations (Nelson et al. 2011).

Upon decomposition, OPEFB acts as a compost fertilizer that aids nutrient cycling, primary productivity, and soil carbon stabilization (Hättenschwiler et al. 2005; Tao et al. 2016). Compost fertilizers derived from OPEFB also enhance soil fauna feeding activity through the presence of decomposer microbes, and they increase the concentration of base cations and soil moisture, which improves soil quality (Tao et al. 2016). Empty fruit bunch can retain water and release it gradually into the soil, and it can improve soil fertility and productivity due to better aeration and decrease soil erosion due to the improvement of the physical and chemical characteristics that contribute to sturdy soil structure (Abdullah and Sulaiman 2013; Syakir et al. 2016). 


\section{Sisal Fiber}

Sisal (Agave sisalana), which constitutes $2 \%$ of global plant fiber production, originates from southern Mexico and is extensively cultivated and naturalized in many other countries, particularly in tropical and subtropical countries with temperatures above $25{ }^{\circ} \mathrm{C}$, and it has a life span from 7 to 10 years. It cannot be cultivated in moist, saline soil conditions, such as clay. Each of its sword-shaped leaves consists of approximately 1000 fibers, which constitutes $4 \%$ of the total fiber in the plant. Sisal fiber is extracted by stripping off the leaves using a rotating wheel set with blunt knives. The drying process is the most crucial part, as moisture content determines the quality of the fiber. Although artificial drying is reported to yield better grades of fiber compared to sun drying, it is not practical in developing countries where sisal is produced. The sisal fiber is traditionally used for manufacturing string, rope, and twine. Presently, sisal fiber is used in the automotive industry as a strengthening agent in composite materials and in the paper industry due to its high cellulose and hemicellulose contents.

Sisal fiber is also used for marine and agricultural cordage and in the carpet and textile industries. In addition, Sisal fiber is used to make sisal geotextiles, which are designed to protect soil by creating a micro-climate for seedlings until vegetation is established. Sisal fiber has a longer life span than jute; thus, sisal geotextiles are beneficial when applied on riverbanks or for extreme applications where plant growth is gradual (Smith 2000). When tested on a 17\% land slope, sisal geotextile demonstrated better erosion control than jute and coir geotextiles due to its high-water absorption capacity (Ram et al. 2009). Similar to kenaf fiber, sisal fiber has low moisture absorption (Giridhar and Rao 1986; Methacanon et al. 2010) and high strength (Methacanon et al. 2010).

These two unique properties indicate the good performance of sisal geotextiles, as strength and durability are vital characteristics in soil erosion control(Methacanon et al. 2010). Sisal fiber reinforced soils with cement increased the tensile behavior (Mattone 2005; Mwasha 2009) and decreased the bulk density of soil (Mattone 2005). Sisal fiber also significantly improved the shear stress of soil via earth reinforcement, as an increase in fiber length reduces the shear stress, which leads to the interlock failure between soil and fiber particles to cooperate as a single coherent matrix (Prabakar and Sridhar 2002).

\section{Hemp Fiber}

Cannabis sativa or hemp is typically found in the northern hemisphere and grows to a height of 6 to $12 \mathrm{ft}$. It is cultivated for the industrial uses of its derived products, including its stalk, which consists of two type of fibers, long fibers (bast) and short fibers (core). In contrast with other trees, hemp is ready to be harvested 2 to 4 months after being planted. In addition, it can grow in most types of soil and climates with moderate nursery management. Extraction of hemp fiber can be completed by two methods, which include retting (traditional method) or thermo-mechanical pulping (modern method). There have been controversies regarding the prohibition of cultivation and usage of hemp fiber in the U. S., as it was claimed to be the main source for the recreational drug marijuana. However, it has been verified that industrial hemp and marijuana come from different breeds of Cannabis sativa. Thus, industrial hemp has no value as a recreational drug (Yonavjak 2013). The superior properties of hemp fiber, such as its strength, durability, and absorbency are currently in demand in a wide range of industries and applications. It is typically blended with other fibers, such as wheat straw or flax, to increase its mechanical properties for use in textiles, rope, twine, paper, and building materials. 
Hemp fiber is also used to control soil erosion. Geotextiles made from hemp fiber are designed to prevent soil erosion by stabilizing new plantings while they develop root systems along the slope, thus reducing the growth of weeds on bare soils. However, unlike geotextiles made from coir fiber, hemp degrades rapidly over a few months when exposed to water and soil, which makes it unsuitable for long-term applications (Karus et al. 2000). However, Small and Marcus (2002) disapproved of this statement and stated that a longlife span is an undesirable attribute in geotextiles, and the most vital aspect is the choice of a vegetation crop type that has the ability to develop root systems in a short period of time (Lekha 2004). The hemp plant possesses long tap roots that help to hold soil particles together, inhibit soil erosion, and increase soil aeration. Organic matter originating from hemp plants also improves soil fertility and helps decrease the usage of fertilizers in farmland. In this way, soil damaged by compaction and erosion can be repaired and restored. In addition, this method can reduce nitrogen pollution in water bodies due to soil leaching.

\section{Coir Fiber}

Coir or coconut fiber is extracted from the mesocarp tissue or husk of the coconut (Cocos nucifera). One thousand coconuts can supply enough raw material to produce 10 $\mathrm{kg}$ of coir. Coir fiber has high concentrations of lignin and lower decomposition rates than other natural fibers, which makes it the most suitable candidate for outdoor applications. Coir fiber can be divided into two types: brown fiber and white fiber. Brown fiber is extracted from mature coconuts and thus contains more lignin and less cellulose, whereas white fiber is extracted from immature green coconuts, which causes it to be smoother and finer but less durable. Conventionally, retting is conducted for several months to extract coir from coconut fruits. As technology has advanced, coconut defibering machines have been widely used on account of their practicality and time efficiency.

Coir fiber is used in rope, sack, brushes, doormats, rugs, insulation panels, packaging, and automobile body panels. Typically, brown coir is more frequently used than white coir due to its high durability. Coir fiber is an abundant and renewable resource with a very low decomposition rate as and higher shear stress than other natural fibers, which makes it suitable for controlling soil erosion. In a soil burial test with identical soil humidity and temperature conducted by the German Federal Institute for Material Testing, cotton and jute fibers took only $6 \mathrm{w}$ and $8 \mathrm{w}$, respectively, to disintegrate, whereas coir fiber took more than a year to degrade (Rao 2002). In addition, it has an outstanding tensile strength that is resistant in various climates and conditions (Karus et al. 2000).

Geotextiles made from coir fibers were reported to successfully initiate vegetation growth in a short period of time due to the presence of sufficient water and light that encouraged seed germination. Compared to flax and hemp fibers that disintegrate rapidly in a few months, coir fiber has long-term stability due to its high lignin content (40\% to $50 \%$ ) and low cellulose content, and it is cheaper than flax and hemp fibers (Gupta 1991; Pritchard 1999; Karus et al. 2000). The tensile strength of coir geotextile decreases to 70\% after 7 months of application (Vishnudas et al. 2008). Vishnudas et al. (2012) stabilized cultivated slope land by using coir geotextiles and found that slopes with crops treated with geotextiles had higher moisture content and less soil erosion than the control plots with geotextiles alone and no crops.

In addition, coir fiber is naturally resistant to seawater; therefore, it can be used to protect coastlines from erosion and prevent further deterioration along shores. It also has high endurance against high velocities of water flow and is suitable for application on steep 
slopes, as it increases soil water infiltration and provides sufficient protection from erosion by impeding rapid water flow (Gupta 1991). For instance, compared to unprotected soil, coir nettings decrease soil erosion $99.6 \%$ during the pre-monsoon season, $95.7 \%$ during the monsoon season, and $78.1 \%$ during the post-monsoon season (Lekha 2004). Beyond the enhanced infiltration of soil, coir-based rolled erosion systems delay the time for soil runoff, reduce intensity of rill incision, and reduce soil loss compared to bare soil (Sutherland and Ziegler 2007). Yadav and Tiwari (2016) reinforced clay soil with alkalinetreated coir fiber $(1 \%)$ and pond ash (10\%). They found that the addition of pond ash and fiber decreases the dry unit weight and increases water retention capacity, compressive strength, split tensile strength, and axial strain at failure of soil mixtures. Lekha (2004) found that soil structure is improved and the total organic carbon content in soil is enhanced through the application of coir fiber.

\section{Bagasse}

Sugarcane (Saccharum officinarum) can grow up to $3 \mathrm{~m}$ to $5 \mathrm{~m}$ in height and is typically cultivated in tropical and subtropical climate zones, such as China, Brazil, and Thailand. The sugarcane plant produces sugar (mainly in the form of sucrose). The fibrous waste residues that remain after the squeezing of sugarcanes during sugar production are known as bagasse. Generally, bagasse contains approximately $40 \%$ to $60 \%$ cellulose (Alavez-Ramirez et al. 2012). Globally, the output of bagasse fibers is estimated to be 75 million metric tons per year (Rowell 1998). Bagasse is currently used in various industries such as the construction, packaging, disposable tableware, paper and pulp, agricultural, and fuel industries. In addition, bagasse is used to generate heat and electricity in sugar mills, to control soil erosion by mulching, and produce geotextile mats (Fortes et al. 2012; Carvalho et al. 2013). Bagasse mulch improves carbon and nutrient cycling (Fortes et al. 2012), water retention (Dourado-Neto et al. 1999), and the structure of the soil (Graham et al. 2002). In addition, bagasse contains beneficial nutrients needed by plant growth, including N, P, K, and Ca (Graham et al. 2002; Fortes et al. 2012; Trivelin et al. 2013).

Bagasse geotextiles are among the natural fiber geotextiles that are fully biodegradable due to their high lignin content, which provides a natural adhesive to entangle the fiber mat together (Collier et al. 1997). The cited authors found that bagasse mat maintained its superior structure even after being tested in heavy rains, whereas woven coir net shrank after the first rainstorm. However, bagasse mats have a slow vegetation growth rate due low light penetration. Dang et al. (2016) found that the mixture of bagasse fiber and hydrated lime enhanced the compressive strength of expansive soil.

\section{Wood Fiber}

Wood fibers are cellulosic elements that are obtained from trees and commonly used to make various materials, including paper. Typically, wood fibers are used in the paper and pulp, construction, and wood industries. They are also applied to control soil erosion. Hydraulic mulch is a temporary way to protect exposed soil from erosion with a mixture of shredded wood fiber and a stabilizing emulsion (California Stormwater Quality Association 2003). Isrealsen and Urroz (1990) tested the efficiency of different mulches (wood fiber/tack, silva fiber, straw tack, and regular fiber) in preventing soil erosion by using a rainfall simulator. Results revealed that wood fiber/tack mulch had the lowest soil erosion rate after silva fiber, whereas straw tack mulch showed the highest soil erosion rate of the remaining mulches. 
Water runoff rate was also notably reduced by the wood fiber/tack mulch, followed by silva fiber, straw tack, and regular fiber mulches. The data for the germination of barley seeds, the dry weight, and height of the barley plant showed that the wood fiber/tack mulch and the silva fiber mulch were superior to the straw tack and regular fiber mulches. This was due to the greater degree of seed protection provided by these mulches, which encouraged germination of seeds under warm temperatures. The study also found that long-fibered products performed better than short-fibered ones, whereas products with tackifiers were more efficient than products without tackifiers.

The authors included a disclaimer that the results presented were not conclusive due to the small number of replications (Isrealsen and Urroz 1990). Prats et al. (2017) added that sieved wood fiber was more effective in reducing soil erosion, as a smaller fraction of shredded wood led to a lower soil erosion mitigation capacity and was less cost effective than sieved wood fiber for large-scale applications (Foltz and Wagenbrenner 2010). Mulch application at a rate of $2.6 \mathrm{Mg} \mathrm{ha}^{-1}$ over $70 \%$ ground cover significantly reduced soil erosion and resulted in less formation of drainage channels during intensive rainfall.

\section{Straw}

Agricultural straw is one of the most frequently used materials for soil erosion mitigation, as it is commonly recognized to be the most practical, cheapest, and simplest way to impede soil loss (Foltz and Dooley 2003). Past studies mainly evaluated the effects of straw mulching on the stability of post-fire soil. Straw mulching is more viable than erosion barriers for decreasing soil erosion after severe wildfires, despite low rate application (Fernández and Vega 2016). Many studies agree that at least $60 \%$ of ground coverage is exposed to soil erosion after fires (Johansen et al. 2001; Vega et al. 2005; Cerdà and Doerr 2008). In agreement with Vega et al. (2014), straw mulch that covered approximately $60 \%$ of the affected area reduced soil erosion $70 \%$ during the first month after the fire, whereas erosion barriers reduced soil loss by only $32 \%$ during the first year of application and decreased rapidly afterwards (Fernández and Vega 2016).

However, Fernández-Fernández et al. (2016) claimed that straw mulching has no remarkable impact in reducing soil erosion, which may be due to the moderate rainfall intensity and erosion rates at the time the study was conducted. Prosdocimi et al. (2016) stated that the use of straw mulch resulted in delayed ponding and runoff generation and decreased median water and sediment concentration runoff, which consequently reduced soil erodibility and surface runoff overall. In addition, straw mulching increases water retention, organic content, and the availability of nutrients in soil, which improved the production yield of the crops (Stagnari et al. 2014). In a study conducted by Muñoz et al. (2017) on the physicochemical properties of soil, the application of a plastic mulching system showed positive impacts relative to straw mulching, such as high soil carbon content and soil stability.

However, the eco-physiological conditions for bacteria growth under plastic mulching were less suitable than under straw mulching, where there was a decline in the number of bacteria and soil fungi and an increase in the production of mycotoxins as a stress sign response by the fungi. Although straw mulch is widely available and has a low specific weight, recent studies have revealed the downsides of straw mulch, which include that its low specific weight allows it to be easily removed by strong winds (Robichaud et al. 2014). In addition, it decomposes easily, especially when compared to wood fibers (Robichaud et al. 2014; Fernández and Vega 2016). 
Table 1. Strengths and Weaknesses of Natural Fibers from Past Studies

\begin{tabular}{|c|c|c|c|}
\hline $\begin{array}{l}\text { Type of } \\
\text { Natural Fiber }\end{array}$ & & & References \\
\hline \multirow{17}{*}{ Jute } & \multirow{15}{*}{ Strengths } & Cost-effective & Mathur et al. 2008; Prodhan 2008 \\
\hline & & Easy to blend with other fibers & Prodhan 2008 \\
\hline & & $\begin{array}{l}\text { Environmentally friendly, and is a biodegradable, renewable } \\
\text { source of energy }\end{array}$ & Mathur et al. 2008; Prodhan 2008 \\
\hline & & Easy installation that does not require expertise & \\
\hline & & Increases the productivity value of land & \\
\hline & & Can maintain water storage capacity in dams and reservoirs & \\
\hline & & $\begin{array}{l}\text { Better sturdiness, high tensile strength, heat resistivity, and high } \\
\text { porosity }\end{array}$ & Hamid and Shafiq 2017 \\
\hline & & Increases the hydraulic conductivity of soil & Sanyal 2008 \\
\hline & & High mechanical properties & Prodhan 2008 \\
\hline & & High water absorption and water retention & $\begin{array}{l}\text { Aggarwal and Sharma 2010; Kumar and } \\
\text { Jagan } 2016\end{array}$ \\
\hline & & Increases the growth rate of vegetation & Choudhury and Sanyal 2010 \\
\hline & & Long life span & Kumar and Jagan 2016 \\
\hline & & Degrades within 1 year to 2 year & Choudhury and Sanyal 2010 \\
\hline & & $\begin{array}{l}\text { Suitable for separation, reinforcement, filtration, and drainage } \\
\text { purposes; it is comparable to synthetic geotextile }\end{array}$ & Mathur et al. 2008 \\
\hline & & Good reinforcement material & Kumar and Jagan 2016 \\
\hline & \multirow[t]{2}{*}{ Weaknesses } & $\begin{array}{l}\text { Swells and degrades within six months of immersion in water, is } \\
\text { fragile in acidic, alkaline, and other solutions, and has rapid } \\
\text { biodegradability }\end{array}$ & Prodhan 2008 \\
\hline & & Results in decreased permeability and penetration of soil & Ghosh et al. 2014; Zaidi et al. 2016 \\
\hline \multirow{4}{*}{ Kenaf } & \multirow{4}{*}{ Strengths } & $\begin{array}{l}\text { Accumulates carbon dioxide in high concentration and absorbs } \\
\text { nitrogen and phosphorus from soil }\end{array}$ & Michell 1986 \\
\hline & & Low density, high mechanical properties, recyclable & Mohanty et al. 2000; Nishino et al. 2003 \\
\hline & & Good reinforcement material & Nishino et al. 2003 \\
\hline & & $\begin{array}{l}\text { Grows well in a wide range of climate and soil types (e.g., high } \\
\text { organic peat soil to sandy desert soil) }\end{array}$ & $\begin{array}{l}\text { Dempsey 1975; LeMahieu et al. 1991; Terry } \\
\text { and Reichert 1999 }\end{array}$ \\
\hline
\end{tabular}




\begin{tabular}{|c|c|c|c|}
\hline & & High tolerance to drought conditions & Webber, III et al. 2002 \\
\hline & & High protein content, good digestibility, and may be pelletized & Webber, III and Bledsoe 1993 \\
\hline & & Low moisture absorption and high strength & Artidteang et al. 2012 \\
\hline & \multirow{3}{*}{ Weaknesses } & Uneven fiber distribution & Zampaloni et al. 2007 \\
\hline & & $\begin{array}{l}\text { Cost depends on the quality and cleanliness of fiber (ranging } \\
\text { from RM } 1.43 \text { to RM } 3.81 \text { per } \mathrm{kg} \text { ) }\end{array}$ & Feng et al. 2001 \\
\hline & & $\begin{array}{l}\text { Form weak bonding interactions with other materials and have } \\
\text { high moisture absorption }\end{array}$ & Tserki et al. 2006; Edeerozey et al. 2007 \\
\hline \multirow{5}{*}{ OPEFB } & \multirow{4}{*}{ Strengths } & High availability and low cost & Rozman et al. 2000 \\
\hline & & High toughness & John et al. 2008 \\
\hline & & Good resistance to oxidation and heat & Sumathi et al. 2008 \\
\hline & & Contains few carbohydrates and has a low risk for termite attack & Zaidon et al. 2008 \\
\hline & Weaknesses & $\begin{array}{l}\text { Low wettability and lack of adhesive penetration due to the } \\
\text { presence of residual oil }\end{array}$ & Paridah and Zaidon 2000 \\
\hline \multirow{6}{*}{ Sisal } & \multirow{4}{*}{ Strengths } & Longer life span than jute & Smith 2000 \\
\hline & & Higher tensile strength than coconut fiber & Kirby 1963; Mwasha 2009 \\
\hline & & More compact structure than jute fiber & Giridhar and Rao 1986 \\
\hline & & $\begin{array}{l}\text { Locally accessible, can be manufactured by small-scale industry, } \\
\text { and requires minimal inputs and management }\end{array}$ & Ram et al. 2009 \\
\hline & \multirow[b]{2}{*}{ Weaknesses } & Higher cost than jute & Giridhar and Rao 1986 \\
\hline & & Poor interaction between fiber and resin in composites & Giridhar and Rao 1986 \\
\hline \multirow{3}{*}{ Hemp } & \multirow[b]{2}{*}{ Strengths } & High tensile strength and wet strength & Lekha 2004 \\
\hline & & $\begin{array}{l}\text { High durability, easy to produce, lightweight, not flammable, and } \\
\text { resistant to weather }\end{array}$ & Hutmacher et al. 2015 \\
\hline & Weaknesses & Short life span & Karus et al. 2000 \\
\hline \multirow{3}{*}{ Coir } & \multirow[b]{3}{*}{ Strengths } & $\begin{array}{l}\text { High durability, high resistance to seawater, abundant, low } \\
\text { decomposition rate, and high shear stress }\end{array}$ & Rao 2002 \\
\hline & & High tensile strength & Karus et al. 2000 \\
\hline & & $\begin{array}{l}\text { Initiates vegetation growth in a short period of time, has long term } \\
\text { stability, and is affordable }\end{array}$ & $\begin{array}{l}\text { Gupta 1991; Pritchard 1999; Karus et al. } \\
2000\end{array}$ \\
\hline
\end{tabular}




\begin{tabular}{|c|c|c|c|}
\hline \multirow{4}{*}{ Bagasse } & \multirow{3}{*}{ Strengths } & $\begin{array}{l}\text { Very stable and sturdy, good thermal properties (suitable at }-25 \\
{ }^{\circ} \mathrm{C} \text { to } 220^{\circ} \mathrm{C} \text { ), decomposable, and has high water resistance }\end{array}$ & Collier et al. 1997 \\
\hline & & Low cost and simple treatment methods & Dinu 2006 \\
\hline & & Availability of raw material & Collier et al. 1997 \\
\hline & Weaknesses & $\begin{array}{l}\text { Lower light penetration that slows the germination of seeds } \\
\text { relative to straw and wood geotextiles }\end{array}$ & Collier et al. 1997; Thames 1997 \\
\hline \multirow[t]{3}{*}{ Wood } & Strengths & $\begin{array}{l}\text { Wood fiber mulch provides maximum protection for seeds to } \\
\text { germinate }\end{array}$ & Isrealsen and Urroz 1990 \\
\hline & \multirow[b]{2}{*}{ Weaknesses } & $\begin{array}{l}\text { Short life span, requires } 24 \mathrm{~h} \text { to dry before rainfall occurs and } \\
\text { requires a second application to remain operative in rainy season }\end{array}$ & $\begin{array}{l}\text { California Stormwater Quality Association } \\
2003\end{array}$ \\
\hline & & $\begin{array}{l}\text { May be less effective than straw, may reduce vegetation } \\
\text { establishment if applied too thickly, easily washed or blown away, } \\
\text { and more expensive than straw mulch }\end{array}$ & Rivas 2006 \\
\hline \multirow{4}{*}{ Straw } & \multirow{3}{*}{ Strengths } & Cheap, widely available, practical, and easy to use & Foltz and Dooley 2003 \\
\hline & & Lower degradation rate than bark strands & Fernández and Vega 2013 \\
\hline & & Efficiently reduces erosion immediately after application & Prosdocimi et al. 2016 \\
\hline & Weaknesses & $\begin{array}{l}\text { Degrades rapidly, may introduce weeds, and is easily removed } \\
\text { by wind and water due to light weight }\end{array}$ & $\begin{array}{l}\text { Robichaud et al. 2014; Fernández and Vega } \\
2016\end{array}$ \\
\hline
\end{tabular}


Table 2. Chronology of Soil Erosion Control Using Raw Natural Fibers

\begin{tabular}{|c|c|c|c|c|c|c|c|}
\hline No. & Soil Erosion Mitigation Method & Type of Soil & $\begin{array}{l}\text { Slope } \\
\text { Steep- } \\
\text { ness }\end{array}$ & $\begin{array}{l}\text { Type of } \\
\text { Erosion }\end{array}$ & $\begin{array}{l}\text { Categories } \\
\text { of anti-erosion } \\
\text { strategies }\end{array}$ & Results & References \\
\hline 1. & Manure and wheat straw mulching & $\begin{array}{l}\text { Gray brown } \\
\text { podzolic } \\
\text { Canfield silt } \\
\text { loam }\end{array}$ & $\begin{array}{c}2 \% \text { to } \\
3 \%\end{array}$ & - & $\begin{array}{l}\text { Direct } \\
\text { spreading of } \\
\text { fibers on soil }\end{array}$ & $\begin{array}{l}\text { Manure mulch reduced soil erosion } \\
\text { from } 12.2 \text { tons per acre to less than half } \\
\text { a ton. Straw mulch increased water } \\
\text { infiltration, which reduced soil erosion. }\end{array}$ & $\begin{array}{l}\text { Borst and } \\
\text { Medersk } 1957\end{array}$ \\
\hline 2. & $\begin{array}{l}\text { Straw, gravel, and soil treated with } \\
\text { dioctadecyl dimethyl ammonium } \\
\text { chloride (DDAC) }\end{array}$ & Austin clay & $4 \%$ & - & $\begin{array}{l}\text { Mulch that is } \\
\text { composed of } \\
\text { fibers and } \\
\text { other } \\
\text { ingredients }\end{array}$ & $\begin{array}{l}\text { Straw and gravel mulches increased } \\
\text { water filtration, reduced runoff, and } \\
\text { eliminated erosion. }\end{array}$ & Adams 1966 \\
\hline 3. & Straw mulch & $\begin{array}{l}\text { Fox loam soil } \\
\text { (Typic Hapludalf) }\end{array}$ & $15 \%$ & - & $\begin{array}{c}\text { Direct } \\
\text { spreading of } \\
\text { fibers on soil }\end{array}$ & $\begin{array}{l}\text { Straw mulch was highly effective in } \\
\text { reducing erosion even when used in } \\
\text { small amounts. }\end{array}$ & $\begin{array}{l}\text { Meyer et al. } \\
1970\end{array}$ \\
\hline 4. & Straw mulch & $\begin{array}{l}\text { Russell silt loam } \\
\text { (Typic Hapludalf) }\end{array}$ & $\begin{array}{l}2 \%, \\
6 \% \\
12 \%, \\
\text { and } \\
20 \%\end{array}$ & Interill & $\begin{array}{l}\text { Direct } \\
\text { spreading of } \\
\text { fibers on soil }\end{array}$ & $\begin{array}{l}\text { Straw mulch was highly effective in } \\
\text { reducing erosion even used in small } \\
\text { amounts. }\end{array}$ & $\begin{array}{l}\text { Lattanzi et al. } \\
1974\end{array}$ \\
\hline 5. & Rice (Oryza sativa) straw & $\begin{array}{l}\text { Clayey keletal, } \\
\text { kaolinitic, } \\
\text { ishyperthermic } \\
\text { Oxic Paleustalf }\end{array}$ & $5 \%$ & - & $\begin{array}{l}\text { Direct } \\
\text { spreading of } \\
\text { fibers on soil }\end{array}$ & $\begin{array}{l}\text { Increases in the mulch rate reduced } \\
\text { soil degradation rates by enhancing } \\
\text { soil structure and water infiltration. }\end{array}$ & Lal et al. 1980 \\
\hline 6. & Corn and soybean residues & $\begin{array}{l}\text { Silty clay loam } \\
\text { soil and silt loam } \\
\text { soil }\end{array}$ & $\begin{array}{c}5 \% \text { and } \\
10 \%\end{array}$ & - & $\begin{array}{l}\text { Direct } \\
\text { spreading of } \\
\text { fibers on soil }\end{array}$ & $\begin{array}{l}20 \% \text { coverage of either residue on soil } \\
\text { reduced soil loss by more than } 50 \% \text {. } \\
\text { Corn residue was more efficient than } \\
\text { soybean in controlling soil erosion. }\end{array}$ & $\begin{array}{l}\text { Dickey et al. } \\
1985\end{array}$ \\
\hline 7. & Sorghum and soybean residues & Sharpsburg soil & $6.4 \%$ & $\begin{array}{l}\text { Rill \& } \\
\text { interill }\end{array}$ & $\begin{array}{l}\text { Direct } \\
\text { spreading of } \\
\text { the fibers on } \\
\text { soil }\end{array}$ & $\begin{array}{l}\text { Increased surface cover caused } \\
\text { reduction of runoff, sediment } \\
\text { concentration, and sediment loss. }\end{array}$ & $\begin{array}{l}\text { Gilley et al. } \\
1986\end{array}$ \\
\hline
\end{tabular}




\begin{tabular}{|c|c|c|c|c|c|c|c|}
\hline 8 & Corn residues & Monona soil & $5.2 \%$ & & $\begin{array}{c}\text { Direct } \\
\text { spreading of } \\
\text { the fibers on } \\
\text { soil }\end{array}$ & $\begin{array}{l}\text { Soil loss rate, runoff, and sediment } \\
\text { concentration decreased as the } \\
\text { amount of corn residues increased. }\end{array}$ & $\begin{array}{l}\text { Gilley et al. } \\
1986\end{array}$ \\
\hline 9. & Rice straw mulch & Alfisols & - & - & $\begin{array}{l}\text { Direct } \\
\text { spreading of } \\
\text { the fibers on } \\
\text { soil }\end{array}$ & $\begin{array}{l}\text { Straw mulch absorbed the impacts of } \\
\text { rainfall and avoided the break down } \\
\text { and dispersion of soil aggregates. }\end{array}$ & Perrier 1987 \\
\hline 10. & $\begin{array}{c}\text { Phosphogypsum (PG)/anionic } \\
\text { polyacrylamide (PAM) (spraying } \\
\text { method) }\end{array}$ & $\begin{array}{l}\text { Sandy loam soil, } \\
\text { Typic } \\
\text { Chromoxerert, } \\
\text { Typic Rhodoxeralf, } \\
\text { and Calcic } \\
\text { Haploxeralf }\end{array}$ & $15 \%$ & - & $\begin{array}{l}\text { Mulch that is } \\
\text { composed of } \\
\text { fibers and } \\
\text { other } \\
\text { ingredients }\end{array}$ & $\begin{array}{l}\text { The addition of PAM and PG } \\
\text { significantly increased soil infiltration } \\
\text { and reduced erosion compared to the } \\
\text { addition of PG only. }\end{array}$ & $\begin{array}{l}\text { Smith et al. } \\
\text { 1990; Levin et } \\
\text { al. } 1991\end{array}$ \\
\hline 11. & Farmyard manure and rice straw & Patancheru series & $2 \%$ & Splash & $\begin{array}{l}\text { Mulch that is } \\
\text { composed of } \\
\text { fibers and } \\
\text { other } \\
\text { ingredients }\end{array}$ & $\begin{array}{l}\text { Rice (Oryza sativa) straw significantly } \\
\text { reduced soil runoff compared to } \\
\text { farmyard manure. }\end{array}$ & $\begin{array}{l}\text { Smith et al. } \\
1992\end{array}$ \\
\hline 12. & $\begin{array}{l}\text { Anionic PAM, cationic polysaccharide } \\
\text { (PSD) }\end{array}$ & $\begin{array}{l}\text { Calcic Haploxeralf } \\
\text { and grumusol } \\
\text { (Typic } \\
\text { Chromoxerert) }\end{array}$ & $15 \%$ & Interill & $\begin{array}{l}\text { Mulch that is } \\
\text { composed of } \\
\text { fibers and } \\
\text { other } \\
\text { ingredients }\end{array}$ & $\begin{array}{l}\text { PAM treatment significantly reduced } \\
\text { soil losses and increased infiltration } \\
\text { compared to PSD treatment. }\end{array}$ & Levy et al. 1992 \\
\hline 13. & PAM (spraying method) & $\begin{array}{l}\text { Calcic Haploxeralf } \\
\text { and dark brown } \\
\text { grumusol (Typic } \\
\text { Chromoxerert) }\end{array}$ & $5 \%$ & Rill & $\begin{array}{l}\text { Mulch that is } \\
\text { composed of } \\
\text { fibers and } \\
\text { other } \\
\text { ingredients }\end{array}$ & $\begin{array}{l}\text { PAM reduced soil loss approximately } \\
94 \% \text { and increased infiltration } \\
\text { approximately } 15 \% \text { when applied at } \\
\text { rates of more than } 0.7 \mathrm{~kg} \text { per hectare. }\end{array}$ & $\begin{array}{l}\text { Shainberg et al. } \\
\text { 1990; Lentz and } \\
\text { Sojka } 1994\end{array}$ \\
\hline 14. & Anionic PAM (spraying method) & $\begin{array}{l}\text { Portneuf silt loam, } \\
\text { clay loam, and silt } \\
\text { loam }\end{array}$ & $\begin{array}{l}1.1 \% \text {, } \\
35 \% \\
\text { and } 45 \%\end{array}$ & - & $\begin{array}{l}\text { Mulch that is } \\
\text { composed of } \\
\text { fibers and } \\
\text { other } \\
\text { ingredients }\end{array}$ & $\begin{array}{l}\text { Soil erosion was reduced } 70 \% \text { and } \\
\text { increased infiltration } 30 \% \text {. }\end{array}$ & $\begin{array}{l}\text { Trout et al. } \\
\text { 1995; Flanagan } \\
\text { et al. } 2002\end{array}$ \\
\hline 15. & Coconut fiber mat & Tropudult & $9 \%$ & - & $\begin{array}{l}\text { Preparation of } \\
\text { mats to be } \\
\text { spread on soil }\end{array}$ & $\begin{array}{l}\text { Runoff and soil loss were reduced, } \\
\text { and soil moisture increased }\end{array}$ & Mapa 1996 \\
\hline
\end{tabular}




\begin{tabular}{|c|c|c|c|c|c|c|c|}
\hline 16. & $\begin{array}{l}\text { Composted municipal solid wastes } \\
\text { (CMSW) }\end{array}$ & Calcic Haploxeralf & $5 \%$ & - & $\begin{array}{l}\text { Direct } \\
\text { spreading of the } \\
\text { fibers on soil }\end{array}$ & $\begin{array}{l}\text { Mulching with CMSW was beneficial } \\
\text { in controlling runoff as it increased } \\
\text { the absorption of water into the soil to } \\
85 \%\end{array}$ & $\begin{array}{l}\text { Agassi et al. } \\
1998\end{array}$ \\
\hline 17. & $\begin{array}{l}\text { Natural mulches: Gossypium } \\
\text { hirsutum L., wood wastes-cotton } \\
\text { fibers, Piptadeniastrum africanum- } \\
\text { cotton fibers, peat-cellulose, jute } \\
\text { fibers, (Corchorus spp.) treated with } \\
\text { mineral oil, kenaf (Hibiscus } \\
\text { cannabinus L.)- cotton, pine straw, } \\
\text { and Bermuda grass (Cynodon } \\
\text { dactylon (L.) Pers.) } \\
\text { Natural/synthetic mulches: Cellulose } \\
\text { fiber/ polypropylene, cellulose/ } \\
\text { polypropylene/ polyethylene, cotton/ } \\
\text { polyethylene, hemlock (Tsuga } \\
\text { spp.)/polyester fiber, woven wood/ } \\
\text { polypropylene, kraft paper } \\
\text { sheet/fiber glass, kraft paper } \\
\text { sheet/nylon, and embossed poplar } \\
\text { (Populus spp.)/ polypropylene } \\
\text { Synthetic mulches: Black } \\
\text { polyethylene, polyester, } \\
\text { polyethylene, and polypropylene }\end{array}$ & $\begin{array}{l}\text { Beauregard silt } \\
\text { loam }\end{array}$ & $0 \%$ to $3 \%$ & - & $\begin{array}{l}\text { Non-biological } \\
\text { mulches }\end{array}$ & $\begin{array}{l}\text { Synthetic mulches were more durable } \\
\text { than natural or natural/synthetic } \\
\text { mulches. Pine straw, cotton- } \\
\text { polyethylene, woven wood- } \\
\text { polypropylene, and synthetic/ } \\
\text { cellulose mat had fair to good } \\
\text { durability after three growing } \\
\text { seasons. }\end{array}$ & Haywood 1999 \\
\hline 18. & $\begin{array}{l}\text { Straw, rice straw, straw/coconut, } \\
\text { coconut, and aspen fibers } \\
\text { (excelsior) }\end{array}$ & Sandy clay loam & $60 \%$ & - & $\begin{array}{l}\text { Mulch that is } \\
\text { composed of } \\
\text { fibers and other } \\
\text { ingredients }\end{array}$ & $\begin{array}{l}\text { The use of mulch reduced soil loss by } \\
81 \% \text { compared to bare soil. }\end{array}$ & $\begin{array}{l}\text { McCullah and } \\
\text { Howard } 2000\end{array}$ \\
\hline 19. & $\begin{array}{l}\text { Organic wastes: Stabilized municipal } \\
\text { waste (compost), unstabilized } \\
\text { municipal waste, and sewage sludge }\end{array}$ & Xeric Torriorthent & $15 \%$ & - & $\begin{array}{l}\text { Mulch that is } \\
\text { composed of } \\
\text { fibers and } \\
\text { other } \\
\text { ingredients }\end{array}$ & $\begin{array}{l}\text { Compost significantly reduced soil } \\
\text { loss by } 94 \% \text { and runoff by } 54 \% \\
\text { compared to other organic wastes. }\end{array}$ & Ros et al. 2001 \\
\hline
\end{tabular}




\begin{tabular}{|c|c|c|c|c|c|c|c|}
\hline 20. & $\begin{array}{l}\text { Coir/jute fiber treated with cationic } \\
\text { softener }\end{array}$ & & & & $\begin{array}{l}\text { Preparation of } \\
\text { mats to be } \\
\text { spread on soil }\end{array}$ & $\begin{array}{l}\text { The materials were non-polluting, } \\
\text { renewable, and controlled erosion by } \\
\text { re- establishment of vegetation. }\end{array}$ & Banerjee 2001 \\
\hline 21. & $\begin{array}{l}\text { Mulching mat comprised of non- } \\
\text { woven geotextile, a jute net, and a } \\
\text { geotextile mat }\end{array}$ & $\begin{array}{l}\text { Decomposed } \\
\text { granite soil }\end{array}$ & $31^{\circ}$ & - & $\begin{array}{l}\text { Preparation } \\
\text { of mats to } \\
\text { be spread } \\
\text { on soil }\end{array}$ & $\begin{array}{l}\text { The materials stabilized the slope of } \\
\text { granite soils and promoted the } \\
\text { growth rate of plants. }\end{array}$ & Ahn et al. 2002 \\
\hline 22. & $\begin{array}{l}\text { Cellulose mulching and black } \\
\text { polyethylene mulching method }\end{array}$ & $\begin{array}{l}\text { Gleysol } \\
\text { hydroamel- } \\
\text { iorated }\end{array}$ & - & - & $\begin{array}{l}\text { Mulch that is } \\
\text { composed of } \\
\text { fibers \& other } \\
\text { ingredients }\end{array}$ & $\begin{array}{l}\text { Black polyethylene mulch reduced } \\
\text { nitrogen leaching better than cellulose } \\
\text { mulching due to its impermeability } \\
\text { and durability. }\end{array}$ & $\begin{array}{l}\text { Romic et al. } \\
2003\end{array}$ \\
\hline 22. & Black polyethylene mulching & Silt loam & - & - & $\begin{array}{l}\text { Mulch that is } \\
\text { composed of } \\
\text { fibers \& other } \\
\text { ingredients }\end{array}$ & & $\begin{array}{l}\text { Green et al. } \\
2003\end{array}$ \\
\hline 23. & Coir geotextile & Sandy loam & $26^{\circ}$ & - & $\begin{array}{l}\text { Preparation of } \\
\text { mats to be } \\
\text { spread on soil }\end{array}$ & $\begin{array}{l}\text { Coir geotextile stimulated the } \\
\text { growth of lemongrass and } \\
\text { improved the organic carbon } \\
\text { content, soil water content, soil } \\
\text { moisture retention, and vegetative } \\
\text { growth of the field area. }\end{array}$ & Lekha 2004 \\
\hline 24. & PAM and phosphogypsum (PG) & $\begin{array}{l}\text { Loamy sand, loam, } \\
\text { and dark brown } \\
\text { clay }\end{array}$ & $15 \%$ & Interill & $\begin{array}{l}\text { Mulch that is } \\
\text { composed of } \\
\text { fibers and } \\
\text { other } \\
\text { ingredients }\end{array}$ & $\begin{array}{l}\text { The PAM mixed with PG reduced soil } \\
\text { susceptibility to seal formation better } \\
\text { than applying only PG on the soil. }\end{array}$ & Tang et al. 2006 \\
\hline 25. & $\begin{array}{c}\text { Elephant grass }(\text { Pennisetum } \\
\text { purpureum) }\end{array}$ & $\begin{array}{l}\text { Sandy loam, } \\
\text { sandy clay loam, } \\
\text { and loamy sand }\end{array}$ & $\begin{array}{l}6 \%, 9 \% \\
\text { and } 12 \%\end{array}$ & - & $\begin{array}{c}\text { Direct } \\
\text { spreading of } \\
\text { the fibers on } \\
\text { soil }\end{array}$ & $\begin{array}{l}\text { The highest cover of elephant grass } \\
\text { increased the infiltration and reduced } \\
\text { soil loss on sloping land. }\end{array}$ & $\begin{array}{l}\text { Adekalu et al. } \\
2007\end{array}$ \\
\hline 26. & Wheat straw mulch & $\begin{array}{l}\text { Sandy loam and } \\
\text { silt loam }\end{array}$ & - & Splash & $\begin{array}{l}\text { Direct spreading } \\
\text { of the fibers on } \\
\text { soil }\end{array}$ & $\begin{array}{l}\text { Straw mulch decreased the mean } \\
\text { splash loss } 68 \% \text { and increased the } \\
\text { infiltration rate } 54 \% \text { compared to } \\
\text { control soil. The treatment was more } \\
\text { effective in sandy than in silt loam. }\end{array}$ & $\begin{array}{l}\text { Kukal and } \\
\text { Sarkar } 2010\end{array}$ \\
\hline
\end{tabular}




\begin{tabular}{|c|c|c|c|c|c|c|c|}
\hline 27. & Jute geotextile (JGT) & Silty-clay soil & - & Gullies & $\begin{array}{l}\text { Preparation of } \\
\text { mats to be } \\
\text { spread on soil }\end{array}$ & $\begin{array}{l}\text { - Prevented detachment of soil } \\
\text { particles, which inhibited soil erosion } \\
\text { by aiding vegetation growth on } \\
\text { applied area; JGT reduced soil loss } \\
\text { from } 8.8 \text { to } 1.3 \mathrm{~g} \mathrm{~mm}^{-1} \text {. Increased soil } \\
\text { moisture content to } 40 \% \text { to } 50 \%\end{array}$ & $\begin{array}{l}\text { Choudhury and } \\
\text { Sanyal } 2010\end{array}$ \\
\hline 28. & PAM & Silty loam & $25^{\circ}$ & - & $\begin{array}{l}\text { Mulch that is } \\
\text { composed of } \\
\text { fibers \& other } \\
\text { ingredients }\end{array}$ & $\begin{array}{l}\text { Effectively reduced the erosion of } \\
\text { steep sloping land }\end{array}$ & Li et al. 2011 \\
\hline 29. & $\begin{array}{l}\text { Rice straw mat/ PAM/ gypsum, } \\
\text { rice straw mat/ sawdust/ } \\
\text { PAM/gypsum, and rice straw mat/ } \\
\text { chaff/ PAM/gypsum mulches }\end{array}$ & - & $\begin{array}{c}10 \% \text { and } \\
20 \%\end{array}$ & - & $\begin{array}{l}\text { Preparation of } \\
\text { mats to be } \\
\text { spread on soil }\end{array}$ & $\begin{array}{l}\text { The rice straw mat/chaff/PAM/ } \\
\text { gypsum reduced runoff greater than } \\
\text { other mulches. Chaff and sawdust } \\
\text { enhanced surface cover rate, } \\
\text { infiltration, and delayed the time of } \\
\text { initial runoff. }\end{array}$ & Lee et al. 2012 \\
\hline 30. & $\begin{array}{l}\text { Sweetgum (Liquidambar styraciflua) } \\
\text { fruits, riprap, and sod }\end{array}$ & Silt loam & $4.3 \%$ & Rills & $\begin{array}{l}\text { Direct } \\
\text { spreading of } \\
\text { fibers on soil }\end{array}$ & $\begin{array}{l}\text { Sod was the most effective method to } \\
\text { control erosion followed by riprap and } \\
\text { sweetgum balls according to the } \\
\text { appearance of the rills. }\end{array}$ & $\begin{array}{l}\text { Alqusaireen et } \\
\text { al. } 2013\end{array}$ \\
\hline 31. & Rice straw mulch & Sandy loam soil & $30 \%$ & Splash & $\begin{array}{l}\text { Direct } \\
\text { spreading of } \\
\text { fibers on soil }\end{array}$ & $\begin{array}{l}\text { Runoff commencement time was } \\
\text { delayed and runoff volume, sediment } \\
\text { concentration, sediment yield, soil } \\
\text { loss, and splash erosion decreased. }\end{array}$ & $\begin{array}{l}\text { Gholami et al. } \\
2013\end{array}$ \\
\hline 32. & Jute geotextiles & $\begin{array}{l}\text { Peat soil \& } \\
\text { black cotton soil }\end{array}$ & - & - & $\begin{array}{l}\text { Preparation of } \\
\text { mats to be } \\
\text { spread on soil }\end{array}$ & $\begin{array}{l}\text { Jute geotextiles improved soil } \\
\text { properties by increasing infiltration } \\
\text { and strength of the soil. }\end{array}$ & $\begin{array}{l}\text { Ghosh et al. } \\
2014\end{array}$ \\
\hline 33. & Barley straw mulch & Sandy loam & $9 \%$ & Splash & $\begin{array}{l}\text { Preparation of } \\
\text { mats to be } \\
\text { spread on soil }\end{array}$ & $\begin{array}{l}\text { Straw mulch reduced splash erosion, } \\
\text { soil sealing, runoff, and soil loss. It } \\
\text { increased infiltration and drainage. }\end{array}$ & $\begin{array}{l}\text { Gholami et al. } \\
2014\end{array}$ \\
\hline 34. & Rice straw blanket & - & - & - & $\begin{array}{l}\text { Preparation of } \\
\text { mats to be } \\
\text { spread on soil }\end{array}$ & $\begin{array}{l}\text { The rice straw blanket held soil } \\
\text { particles, promoted vegetation } \\
\text { growth, retained moisture, and } \\
\text { prevented loss of } \mathrm{N}, \mathrm{P} \text {, and } \mathrm{K} \text { in soil. }\end{array}$ & $\begin{array}{l}\text { Deshmukh et al. } \\
2015\end{array}$ \\
\hline 35. & Straw mulch & Loamy sand & $35 \%$ & - & $\begin{array}{l}\text { Direct } \\
\text { spreading of } \\
\text { fibers on soil }\end{array}$ & $\begin{array}{l}\text { Sixty percent mulch cover reduced } \\
\text { approximately } 70 \% \text { of soil erosion in } \\
\text { the first month after application. }\end{array}$ & $\begin{array}{l}\text { Fernández and } \\
\text { Vega } 2016\end{array}$ \\
\hline
\end{tabular}


Fernández and Vega (2013) found that straw mulch has a low decomposition rate and encourages rapid vegetation cover recovery better than wood-based mulch. Both types of mulching significantly reduced sediment yield and overland flow velocity, and they increased soil infiltration and vegetation cover (Robichaud et al. 2013).

Generally, past studies indicate that jute is the best candidate to prevent soil erosion due to its superior mechanical and hygroscopic properties relative to other cellulosic fibers. This statement is in agreement with Rickson (2003). Although jute fiber has a short life span, it is possible to delay its biodegradability by up to $20 \mathrm{y}$ via different treatments and blending (Agrawal 2011). According to certain authors (e.g., Gupta 1991) biodegradability is an advantage, as it allows the right amount of time for slopes to establish vegetation. In addition, the decomposition of jute fibers increases soil moisture content and enhances the nutrient contents in soil, which improves the ecological cycle of the applied area. Batra (1985) made a comparison between natural fibers such as jute, coir, and sisal. The water retention capacities of jute and sisal are better than that of coir. This is due to the high lignin content in coir, which decreases absorption because lignin is hydrophobic (Ghosh et al. 2009). The presence of lignin tends to inhibit microbial attack by keeping the fiber surface at low moisture levels (Ghosh et al. 2009). In this regard, the lignin properties in jute fibers exhibit high modulus, tenacity, and very low extension at break, whereas coir fiber exhibits the exact opposite qualities. Rickson (2003) reported that to prevent soil loss, the materials used must be lightweight, non-needle-punched, and woven to provide a conducive condition for vegetation growth where both light and space are available. However, researchers have confirmed that attained ground cover was more critical than the type of material. For instance, different mulches, such as wood strands (Foltz and Dooley 2003; Yanosek et al. 2006), pine needles (Pannkuk and Robichaud 2003; Smets et al. 2008), and wood shreds (Foltz and Copeland 2009), showed the same reduction of total soil loss with ground coverage of $70 \%$. Table 2 summarizes the studies of soil erosion control using natural fibers in sequence.

\section{POTENTIAL APPLICATION OF CELLULOSIC FIBRE FOR SOIL EROSION MITIGATION IN A BIOCOMPOSITE FORM}

A material that incorporates two or more different polymers with at least one component that is bio-based or biodegradable is called a biocomposite. It consists of a matrix that acts as a binder material and dominant natural fibers, acting as a "back-bone" of the biocomposite. However, in the context of this review, the term "biocomposite" will refer to a mixture or blended cellulosic fiber material that is not perceived as a conventional biocomposite description in which fiber acts as reinforcement within a matrix. Most often, the matrix is made from polymers derived from renewable and non-renewable resources and is commonly degradable. The main purpose of the matrix is to transfer the load or stress exerted on the biocomposite to the reinforcement material and protect it from adverse environmental effects. In contrast, the reinforcement's role is to provide mechanical support for the biocomposite, which is why this material commonly consists of either fibers or particles.

In some cases, a compatibilizer is added to enhance the adhesive interaction between matrix and fiber, as the compatibility of materials in a composite is vital in determining the properties and strength of the composite (Barton et al. 2014). Depending on the purpose and type of the biocomposite, the structure can be produced by various 
methods, including machine press, extrusion, injection molding, compression molding, resin transfer molding, and hand layout methods. Biocomposites that have been used to control soil erosion are shown in Table 2. From 2008 until 2012, Restoration Technologies (RT) group, based in the United States, worked on a wood chip composite material (chipped woody biomass and an inorganic cement binder) called Zerosion to create an erosion control material that stabilizes soil quickly and possesses superior mechanical properties to withstand adverse natural impacts and degrade after more than five years after application. Because current erosion control products have low endurance towards the climate, Zerosion was created to have high durability, while at the same time being permeable to water and enhancing vegetation growth. However, there has yet to be a progress report or publication on the development of this material.

Maghchiche et al. (2010) conducted a study to determine the effects of different synthetic polymers and biopolymers at low concentrations $(0.03 \%$ to $1 \%)$ in arid and semiarid soils in North Africa. The cellulose was derived from the alfalfa plant and blended with a poly(acrylamide) (PAM) solution. Different concentrations of cellulose $(0 \mathrm{mg} / \mathrm{L}$ to $20 \mathrm{mg} / \mathrm{L})$ and PAM $(0 \mathrm{~g} / \mathrm{L}$ to $0.5 \mathrm{~g} / \mathrm{L})$ were prepared. They found that the polymer composites $(10 \mathrm{mg} / \mathrm{L}$ polyacrylamide and $0.5 \mathrm{~g} / \mathrm{L}$ cellulose) in soil improved the soil's physical properties and augmented water retention by $60 \%$ in arid soils compared with the application of any other polymer at the same concentration. Snidjer (2010) applied GreenGran (natural fiber/PLA/PHB) granules, which have superior technical properties to previous natural fibers and are comparable to other glass fiber reinforced plastics, onto riverbanks. GreenGran (natural fiber/PLA/PHB) granules are environmentally friendly (they will decompose after a certain period) and can be reused up to seven times. There has been much research interest in soil erosion to find new technologies/materials with which to stabilise soil slopes. Many geosynthetic materials have been developed to stabilise soil slopes; however the integration of biodegradable material utilization that environmentally friendly is timely (Ngo et al. 2019).

The studies shown in Tables 2 and 3 indicate that the research on the application of biocomposites in soil erosion mitigation is limited compared to that on the application of natural fibers. This could be due to poor accessibility and high cost of biodegradable polymers (Sahari and Sapuan 2011) relative to natural fibers, which are abundant and inexpensive (Sapuan and Maleque 2005), have low density, and lack remnants upon incineration (Wollerdorfer and Bader 1998; Leman et al. 2008; Zainudin et al. 2009). Furthermore, instead of focusing on the creation of new products from renewable resources, most of the erosion control measures are focused on mechanical structures $(e . g$., construction of terraces, silt pits, waterways, and gabions) (Mati 2012), cover crops, and mulching as the easiest way to control soil loss (Hartemink 2006). Poor interactions between the matrix and natural fibers due to its hydrophilic nature of fibers, which reduces impact strength (Faruk et al. 2014), is another factor that limits the evolution of biocomposites.

Chemical modification, such as alkaline treatment, is a common technique used to improve the compatibility of matrices with natural fiber reinforced polymers (Bledzki et al. 2012). In addition, the application of biocomposites for outdoor applications is not economical due to the large price fluctuations and variable quality of fiber, and it is susceptible to adverse environmental impacts (fungus attack, weathering, etc.) (Faruk et al. 2014). 


\section{bioresources.com}

Table 3. Biocomposite Materials in Controlling Soil Erosion

\begin{tabular}{|c|c|c|c|c|c|c|c|}
\hline No. & Type of Composites & $\begin{array}{l}\text { Composite Form/ } \\
\text { Method Applied }\end{array}$ & $\begin{array}{c}\text { Type of } \\
\text { Soil/Location }\end{array}$ & $\begin{array}{l}\text { Slope } \\
\text { Steepness }\end{array}$ & $\begin{array}{l}\text { Type of } \\
\text { Erosion }\end{array}$ & Results & References \\
\hline 1. & $\begin{array}{c}\text { Polyacrylamide } \\
\text { (synthetic plastic } \\
\text { compounds)/cellulos } \\
\text { e composite }\end{array}$ & Liquid/spraying & $\begin{array}{c}\text { Arid and } \\
\text { semiarid soil }\end{array}$ & - & - & $\begin{array}{l}\text { Improved physical } \\
\text { properties of soil and } \\
\text { reduced water losses } \\
\text { from evaporation }\end{array}$ & $\begin{array}{l}\text { Maghchiche et al. } \\
\quad 2010\end{array}$ \\
\hline 2. & $\begin{array}{c}\text { Natural } \\
\text { fiber/polylactic acid } \\
\text { (PLA)/ } \\
\text { Polyhydroxybutyrat e } \\
\text { (PHB) composite }\end{array}$ & $\begin{array}{l}\text { Blocks made from } \\
\text { granules/scattering }\end{array}$ & $\begin{array}{l}\text { Riverbank and } \\
\text { dams }\end{array}$ & - & - & $\begin{array}{l}\text { Blocks made from } \\
\text { GreenGran granules } \\
\text { protected the riverbanks } \\
\text { and dams from erosion }\end{array}$ & Snidjer 2010 \\
\hline
\end{tabular}


The type of species, ecological factors, and postharvest handling methods are some of the main factors that affect the quality of natural fibers (Faruk et al. 2014). However, the major drawback of natural fiber is that its mechanical properties depend on its climate, growing conditions, processing technique, and water absorption. Most of the studies involving biocomposites were in the automotive (Oksman et al. 2003; Kim et al. 2011; Faruk et al. 2014), packaging (Bastioli 1998), wood (Fuad et al. 1994; Izani et al. 2013; Ibrahim et al. 2014), household furniture (Sapuan and Maleque 2005), and construction applications (Burgueño et al. 2004; Singh et al. 2010). Several studies (Wollerdorfer and Bader 1998; Avérous and Boquillon 2004; Soykeabkaew et al. 2004; Ma et al. 2005; Tserki et al. 2006; Dittenber and Gangarao 2012; Nagarajan et al. 2013) reported that a biodegradable matrix reinforced with natural fibers enhanced the mechanical properties (e.g., tensile strength, flexural strength, and specific modulus) and the biodegradation rate of composites, and they formed lightweight and eco-friendly composites.

\section{POTENTIAL MATRICES IN BIOCOMPOSITES FROM NATURAL RESOURCES}

Recently, biocomposites consisting of natural fiber and bio-matrices, such as reinforcement material and binders, respectively, have been developed. Bio-matrices are polymer matrices that contain bio-based products, such as starch, cellulose, polylactide, and polhydroxy-alkanoate (PHAs). Matrices made from natural resources are difficult to produce. Despite the abundance of these materials in nature, they are often modified and require processing before being incorporated into biocomposite materials (Toriz et al. 2003).

\section{Sludge}

Sludge in general can be defined as a remaining semi-solid material that is produced as a by-product from industry, water treatment, or wastewater treatment processes. In the U.S., pulp and paper factories produce 4 million dry tons of sludge for each 80 million tons of pulp production per year (Miner and Unwin 1991). The situation is similar for municipal wastewater sludge, where formerly most of the sludge was disposed of by landfilling, ocean dumping, and spreading on the land, which causes various environmental problems. Thus, it is crucial to find different methods for managing sludge waste. To date, there have been few studies on using sludge as a matrix in composites. Instead, many researchers have applied it in cementitious and reinforced materials. Tay (1987) produced bricks for construction and building by mixing wastewater sludge with clay.

Comparisons between the effects of dried sludge and ash sludge on the properties of bricks have been performed. For ash sludge, the sludge was first burned at over $600{ }^{\circ} \mathrm{C}$ in a furnace to eliminate organic matter before it was mixed with clay at $10 \mathrm{wt} \%, 20 \mathrm{wt} \%$, $30 \mathrm{wt} \%, 40 \mathrm{wt} \%$, and $50 \mathrm{wt} \%$, whereas for dried sludge, it was mixed with clay at $10 \mathrm{wt} \%$, $20 \mathrm{wt} \%, 30 \mathrm{wt} \%$, and $40 \mathrm{wt} \%$. Both samples were then fed into an extrusion machine. The suitable percentage of sludge should not exceed more than $40 \mathrm{wt} \%$ and $50 \mathrm{wt} \%$ for dried and ash sludge, respectively, as increasing the percentage of sludge causes an uneven brick surface. Results indicated that the hydrophilicity of bricks increased as sludge percentage increased, which is unfavorable in the building industry as it decreases the robustness of the bricks. A high percentage of sludge also decreased the compressive strength of the bricks, which was in agreement with Nair et al. (2013). In addition, ash sludge bricks have 
better durability than dried sludge bricks. However, the mixture of sludge and clay may not be suitable to be used as a construction material due to the poor surface texture of the bricks produced.

Son et al. (2001) investigated the physical and mechanical properties of paper sludge-thermoplastic polymer composites based on the sludge's particle size and the extrusion temperature exerted on them. In the study, paper sludge, which acts as a reinforcing filler material, was blended with thermoplastic polymers before being introduced into a single-screw extruder and then prepared with an injection-molding machine at $200{ }^{\circ} \mathrm{C}$. Results showed that swelling thickness, water absorption, tensile strength, and flexural strength were improved with smaller sludge particle sizes. This was because smaller particle sizes of sludge, which are mostly comprised of inorganic materials, have higher porosity than larger particle sizes, which enhances water absorption capacity. Further, smaller particle sizes fill up the void spaces in composites, which leads to superior mechanical strength. However, both variables (particle size and temperature) had no effect on the unnotched impact strength test.

In contrast, increasing extrusion temperature had a positive impact on all tests conducted (thickness swelling, water absorption, tensile, flexural, and impact strengths) due to better wettability between the polymer and paper sludge fibers. However, for notched and unnotched impact strength, the impact strengths slightly decreased with an increase in temperature of 230 to $250{ }^{\circ} \mathrm{C}$, which was probably due to thermal decomposition of the composite that caused a failure in effective interfacial adhesion between cellulose and matrix. Overall, paper sludge from industrial waste has a high potential to replace the existing reinforcement filler in thermoplastic polymers (Elloumi et al. 2016). Ingunza et al. (2015) incorporated sewage sludge (at concentrations of $2 \%, 4 \%$, $6 \%, 8 \%$, and $10 \%$ dry mass) with clay to produce ceramic roof tiles. Water absorption increased with the addition of sludge into the clay. This occurred due to the high content of organic matter $(71 \%)$ in the sludge, which caused higher porosity and led to lower mechanical properties of the ceramic roof tiles, as the flexural rupture strength decreased with the augmentation of sludge dosage (Androff et al. 1997). This is the main drawback of using sludge for construction materials. The amount of sludge recommended by Ingunza et al. (2015) in ceramic mass used to manufacture roof tiles was $4 \%$ of dry weight sludge. However, Kutuk and Oguz (2016) found that the tensile strength of their studied composite increased when the content of sewage sludge ash particles was increased to $20 \%$, which was then followed by a decrease in tensile strength when the sewage sludge ash particle content was increased beyond 20\%. Similarly, the impact strength of the composites increased when the content of sewage sludge ash particles was increased to $10 \%$, and it remained constant at $25 \%$ to $40 \%$ sludge ash content.

Using the solution casting technique, Purohit and Satapathy (2017) fabricated composites consisting of epoxy as a matrix, and Linz-Donawitz (LD) wastes (generated from iron and steel industries sludge) functioned as a filler with various weight proportions $(0,5,10,15$, and $20 \mathrm{wt} \%)$. The mechanical properties of the composites were then compared with epoxy-based composites of blast furnace (BF) slag and LD slug from previous studies. The results revealed that epoxy-LD sludge composites exhibit superior mechanical and wear characteristics to epoxy-BF slag and epoxy-LD slug composites. However, the increase of filler loading in composites decreased the tensile strength, increased the flexural strength, and improved the micro-hardness values of epoxy-LD sludge composites. The reduction of tensile strength was mainly due to the inefficient load stress transfer between LD sludge particles and the matrix. The authors concluded that 
there is potential to produce composites from sludge waste and epoxy matrix with the solution casting technique.

\section{Polylactide}

Polylactide or polylactid acid is derived from renewable agricultural raw resources, such as corn starch, tapioca roots, chips, starch, or sugarcane, which are then fermented to lactic acid. It is commonly used in decomposable packaging material and medical implants due to its biodegradability. Depending on the size and type of production, PLA typically takes only a few years to decompose compared to petroleum-based products, which take hundreds to thousands of years to degrade. The decomposition of PLA occurs via the breakdown of compounds by water to lactic acid with the aid of microbes to produce water and carbon dioxide (Oksman et al. 2003). In the future, PLA, which is a by-product, could possibly turn into a carbon sink and contribute to the reduction of greenhouse gases (Dittenber and Gangarao 2012). Oksman et al. (2003) compared the mechanical properties of PLA/flax composite with polypropylene flax fiber composite (PP/flax). They found that the PLA/flax composite had a tensile strength and tensile modulus of $32 \mathrm{MPa}$ and $2.1 \mathrm{GPa}$ higher, respectively, than the PP/flax composite. This means that PLA works well as a matrix with a 50\% improvement in mechanical properties relative to $\mathrm{PP}$, which has been used widely in many industries. This shows the potential of PLA to replace conventional thermoplastic composites as a matrix in natural fiber composites. However, the interfacial adhesion of matrix-fiber should be considered, as it determines the strength of the composite. Ochi (2008) investigated the tensile and flexural strength of unidirectional biocomposites that were fabricated from kenaf fiber and PLA resin at a molding temperature of $160^{\circ} \mathrm{C}$, as kenaf fiber's tensile strength will decrease if the temperature exceeds $180{ }^{\circ} \mathrm{C}$. With $70 \%$ fiber loading, the biocomposite demonstrated high tensile and flexural strengths of 223 and $254 \mathrm{MPa}$, respectively. The kenaf/PLA composites decreased in weight drastically to $38 \%$ after four weeks of evaluation using a garbage-processing machine, which indicates that it is fully biodegradable, as it only releases water and carbon dioxide during the degradation process.

\section{Thermoplastic Starch}

Starch is derived from polysaccharides of wheat, maize, potato, rice, tapioca, and other plants. In the early 1970s, starch was used to produce biodegradable plastics (Curvelo et al. 2001), which then precipitated the evolution of starch. Starch can be processed into 649 thermoplastic starch (TPS) under the action of high temperature and shear forces (Shogren 1992; Forssell et al. 1997). The application of TPS as a matrix in biocomposites has been reported by Hermann et al. (1998) and Bastioli (1998) to be one of the main polymers being extensively studied today by other researchers. Thermoplastic starch has two main drawbacks in that it is water-soluble and has poor mechanical properties (Curvelo et al. 2001). Therefore, TPS that is commonly used in packaging and agricultural applications is blended with other polymers, such as natural fiber in contents that usually exceed $50 \%$ to improve the properties of composites. It is favorable for its renewable, biodegradable, abundant, and low-cost polymer characteristics. Curvelo et al. (2001) prepared biocomposites comprised of TPS and cellulosic fiber from the pulp of Eucalyptus urograndis. Both polymers were mixed at $170{ }^{\circ} \mathrm{C}$ and hot pressed before cutting to a specific size prior to mechanical tests.

Evaluation of the tensile strength showed a $100 \%$ increase, whereas modulus increased more than 50\% compared to non-reinforced TPS. A strong adhesive interaction 
between TPS and cellulose fiber was achieved with $16 \%$ fiber content, as the fiber was homogenously dispersed. The absence of fiber pullout on the surface of the composite due to perfect starch coverage indicated a good adhesion between matrix and fiber (Salilba and Snide 1990). However, water sorption was reduced sharply with the incorporation of fiber. Ma et al. (2005) produced TPS composites by mixing micro winceyette fiber into a matrix derived from urea/formamide-plasticized corn starch before introducing it into a single screw extruder under four heating zones of $120,130,130$, and $110^{\circ} \mathrm{C}$. The tensile strength, water resistance, and thermal stability of the composite were significantly improved due to good adhesion between the starch and fiber. The results demonstrated that, as fiber content increased from $0 \%$ to $20 \%$, tensile strength increased to $15.16 \mathrm{MPa}$, and elongation were reduced from $105 \%$ to $19 \%$.

Further, the addition of water to the contents of the composites decreased its mechanical properties, whereas the introduction of fiber effectively prevented water absorption by the TPS matrix and reduced the water sensitivity of TPS. Torres et al. (2007) studied TPS composites reinforced with sisal, jute, and cabuya with a matrix of potato, sweet potato, and corn starch with a compression molding press to compact the composite at temperatures of 130,150 , and $175^{\circ} \mathrm{C}$. In this study, ethylene glycol, glycerol, propylene glycol, and chitosan were used as plasticizers. The tensile strength exhibited a great improvement of almost $100 \%$ in potato starch/sisal composite, whereas jute and cabuya fiber showed improvements in tensile strength of 54 and 15\%, respectively. When compared with the unreinforced matrix, the impact strengths of potato starch reinforced with jute and cabuya fibers displayed extraordinary improvements of approximately $100 \%$ and 200\%, respectively. Ethylene glycol and glycerol showed better tensile strength compared to the plasticizers used in the study. All plasticizers showed similar results for impact strength except for water, which showed an improvement of up to 35\% compared to propylene glycol and chitosan. Generally, TPS and natural fibers are highly compatible in composites (Avérous and Halley 2009).

\section{SOIL STABILIZER IN OIL PALM PLANTATIONS}

Organic mulches using OPEFB are one of common methods that have been practiced over several decades in oil palm plantations to prevent soil degradation, hence sustaining long-term productivity (Afandi et al. 2017). However, due to it bulky size, the application of OPEFB is limited to matured palm oil areas only. This brought to new opportunity for an innovative OPEFB (and other potential matrix such as sludge) based biocomposite (in a pellet form) to be applied in other areas that are more vulnerable to erosion (Ashikin et al. 2019). The replanting of oil palm will be performed after 25 to 30 years of economic life span of oil palm trees. An oil palm tree starts to mature at 3 years to 4 years after it has been planted. Therefore, the environment, particularly the water bodies, are vulnerable to erosion due to the absence of vegetation cover. Full vegetation cover has lower soil loss than bare soil, as the roots hold soil particles together and reduce raindrop impact (Sahat et al. 2016). Land preparation is the most critical element of oil palm plantations, as erosion and sedimentation occur at an alarming rate during land preparation (PORIM 1994; Ismail 1997).

Exposed soil surfaces accelerate erosion rates, especially during frequent rainfall, which causes significant overland flow that deteriorate the surface water quality (Nor Ashikin et al. (2019). The erosion rate depends on slope steepness and prevention 
measures taken (Sahat et al. 2016). Heavy machinery and tracked vehicles often worsen the situation via soil compaction, which leads to deterioration in soil structure and fertility. In addition, the compaction of soil decreases soil porosity, which reduces infiltration rates. Compacted path surfaces caused by heavy machinery may increase the potential for Horton Overland Flow (HOF) (Ziegler et al. 2001), which leads to soil erosion due to water runoff. Soil erosion tends to happen in mature palm oil plantations because cover crops usually disappear at this stage (Hartemink 2006). Exposed and compacted soil thus intensify run-off and soil erosion Therefore, as soil erosion in oil palm plantations significantly impacts soil health, preventive measures for mitigating soil erosion have been taken for decades. Some of the mitigation measures that have been implemented include early cover crop cultivation, placement of dry prune fronds and old palm trunks along harvesting paths, construction of silt pits, and empty fruit bunch mulching (Palm Oil Research Institute of Malaysia 1994). Clay (2004) proposed that before planting, careful consideration must be given to certain factors, such as soil type and slope of plantation area, as some soils are not suitable for oil palm plantations and may cause adverse impacts in the future.

\section{Principles of Soil Stabilizer}

In the Tenth Malaysia Plan (2011 to 2015), the Malaysian government recognized the importance of environmental sustainability as part of a comprehensive socio-economic development plan, whereby issues, such as climate change, environmental degradation, and sustainable utilization of Malaysia's natural endowment, were addressed. In the Eleventh Malaysia Plan (2016 to 2020), green growth was a fundamental shift in how Malaysia sees the role of natural resources and the environment in its socio-economic development, simultaneously protecting both development gains and biodiversity. Therefore, mitigation of natural hazards, such as floods, has been given serious attention by the Malaysian government in the Eleventh Malaysia Plan, in which innovative solutions through the development of green technology are emphasized and consider the preservation and optimization of land use and the intensity of extreme weather regimes. This represents a continuous commitment of the Malaysian government to sustainability inspired by the National Environmental Policy (2002).

There are many related studies on soil stabilization using chemical agents, such as cementitious and pozzolanic materials (Por et al. 2015, 2017; Chomporat 2019). However, in this review the term "soil stabilizer" refers to reapplication of bio-based resources, especially byproducts from agricultural wastes, back into the soil to stabilize the soil structure. This is achieved by preventing or reducing the impact of raindrops on bare soil surfaces, which typically cause erosion if preventive measures are not taken. Soil erosion can be divided into four primary processes, which are splash erosion, sheet erosion, rill erosion, and gully erosion. Splash erosion is the first and least severe stage in the soil erosion process, followed by sheet erosion, rill erosion, and finally gully erosion, which is the most severe stage. In splash erosion, when raindrops strike bare soil, soil particles disintegrate and disaggregate into fine particles, consequently thrown up to one meter, clog up soil pores, and create a surface seal, which impedes the permeability of water into soil, thus increasing runoff. If no preventive steps are taken to mitigate the first process, then sheet erosion will occur.

Sheet erosion involves the removal of the thin layer of topsoil that comprises most of the nutrients and organic matter in soil. Soil erosion is a gradual process and is often unnoticed. However, it can accelerate to an alarming rate and cause a severe loss of topsoil. 
Soil erosion on steep hillslopes can rapidly evolve from splash or sheet erosion to rill erosion when there is sufficient extra rainfall energy exerted on the soil or if sufficient overland flow occurs (Di Stefano et al. 2013). Rill erosion is the intermediate stage between splash and gully erosion (Jackson 1997). Rills are small channels created by water runoff with a depth of less than $0.3 \mathrm{~m}$. They are commonly seen in cultivated fields and can cause extensive soil losses (Govers and Poesen 1988; Miao et al. 2011), especially during the development of rill networks, as they are significantly affected by rainfall intensity (Shen et al. 2015). Gully erosion is the stage following rill erosion. Gully erosion can be formed by runoff water concentration or by gradual deepening of rills in which the channel depth reaches 2 to $3 \mathrm{~m}$ (Zachar 1982). Normally, this type of erosion is clearly noticeable, as it affects soil productivity and damages roads and buildings (Department of Natural 806 Resources and Water 2006).

Therefore, preventive measures should be taken at the early stages of sheet or rill erosion so that severe soil structure damage can be stopped. This is because, during the first stage (splash erosion), the erosion event occurs without an obvious indication; thus, soil stabilization cannot typically be employed effectively. During gully erosion, the application of soil stabilizer seems to be less effective due to the worsening of soil condition. Meyer et al. (1970) added that mulches are generally ineffective once rills form. Therefore, another soil protection strategy needs to be applied to impede the formation of gullies.

\section{Application of "Green" Resources as Soil Stabilizers in Oil Palm Plantations}

Various strategies have been implemented to stabilize soil structure, including mechanical, physical, and chemical reaction techniques. Soil reinforcement, soil replacement, compaction, and chemical soil stabilization are some of the techniques used to enhance the mechanical properties of soil (Tabatabaee 1985). In oil palm plantations, terracing hills and silt pits that trap water sediments from surface runoff, stacking fronds used to minimize runoff velocity, and leguminous cover crop that helps in restocking soil organic matter content are some of the common practices reported by Mohsen et al. (2014). In this section, the efficiency of controlling soil erosion by using natural resources, such as EFB, oil palm frond, eco-mat, and leguminous cover crop plants, are discussed.

\section{OPEFB mulch}

The introduction of the Malaysian Environmental Air Quality Regulation in 1978 triggered changes in EFB disposal management methods, as EFB was traditionally incinerated due to its wet and bulky properties (Abu Bakar et al. 2011). Mulches originating from fibrous byproducts, such as EFB and fruit mesocarp fibers, are also used as a soil conservation method in oil palm plantations (Basiron 2007). In the oil palm industry, byproducts, such as EFB, are among the most favored natural mulches because they reduce soil erosion and runoff (Lim and Messchalck 1979) and release carbon and other beneficial nutrients during the decomposition process, thus improving soil fertility (Wagner and Wolf 1998). Lord and Clay (2006) suggested the utilization of EFB with palm oil mill effluent (POME) or palm kernel cake as compost materials in nursery bags, as seedling nurseries usually involve the stripping of topsoil, which deteriorates the soil structure. Empty fruit branch ameliorates the soil structure by providing better aeration, increasing water retention, and reducing soil acidity (Hoong and Nadarajah 1988; Abdullah and Sulaiman 2013). 
In addition, empty fruit bunch increases the $\mathrm{pH}$ and aggregate stability of soil more effectively than other treatment methods, such as eco-mats (Ping et al. 2012). Beyond maintaining the soil structure, EFB is a beneficial nutritional source for organic fertilizers and soil conditioning agents, as it contains high nutrient concentrations and releases them gradually into the soil via microbes, thus increasing ecological recycling efficiency (Abdullah and Sulaiman 2013; Mohsen et al. 2014). Studies have shown that EFB-treated soil showed significant increases in total $\mathrm{N}$ and $\mathrm{C}$, and exchangeable $\mathrm{K}, \mathrm{Ca}$, and $\mathrm{Mg}$ (Hamdan et al. 1998). According to Singh et al. (1999), $1000 \mathrm{~kg}$ of EFB has an amount of nutrients comparable with $7.0 \mathrm{~kg}$ of urea, $2.8 \mathrm{~kg}$ of phosphate, $19.3 \mathrm{~kg}$ of rock, and $4.4 \mathrm{~kg}$ of muriate of potash and kieserite, which indicates that this byproduct consists of many minerals and nutrients needed by soil, thus increasing the growth rate of vegetation and reducing soil erosion (Singh et al. 1981).

Although EFB mulching enhances soil nutrient and soil water content, a drawback of EFB is that it decomposes quickly. Often, it becomes ineffective in conserving soil and water approximately 8 months after its application (Khalid and Tarmizi 2008); therefore, re-mulching is required after 6 to 7 months to maintain soil moisture conservation efficiency (Arif et al. 2003). However, Moradi et al. (2012) and Ping et al. (2012) reported that mulching materials, such as EFB, require 12 months to decompose and improve soil chemical and physical properties synchronously. Due to all of the advantages mentioned above, Abu Bakar et al. (2011), Moradi et al. (2012), and Ping et al. (2012) concurred that EFB application is the best practice to preserve soil particles from erosion by improving soil aggregate stability due to its high organic matter content. Pruned oil palm fronds are another form of oil palm waste that is typically used to protect surface soil from direct raindrop impact. Lord and Clay (2006) recommended the application of fronds in mitigating sheet and rill erosion to reduce soil loss and assist in the establishment of natural vegetation. Normally, 24 fronds are stacked together for an oil palm tree (Sulaiman et al. 2012).

This method has been demonstrated by Mohd Ali (1997) to enhance organic matter, aggregate stability, and water content in soil, and decrease soil bulk density. The total organic matter in soil is critical in determining the stability of soil aggregates, as the loss of organic matter results in unstable soil structure (Oades 1988). However, Moradi et al. (2012) and Sahat et al. (2016) found that dried fronds are less effectives in reducing soil erosion rates than other cover crops, such as grass. However, oil palm fronds can be used to slow down surface runoff velocity by acting as surface flow breakers. In addition, Lim (1990) found that pruned fronds can decrease erosion rates on slopes of $3^{\circ}$ to $5^{\circ}$ by averting the direct impact of rain drops. The adjustment of the layout position of dried fronds also needs to be considered, as a layout position perpendicular to groundwater surface flows is more effective in preventing soil loss compared to a layout position parallel to groundwater surface flows (Sahat et al. 2016). Even though pruned fronds release high amounts of nutrients, such as $\mathrm{N}, \mathrm{P}, \mathrm{K}$, and $\mathrm{Mg}$, into soil (Husin et al. 1987), they are a less practical solution to reduce soil loss and enhance soil water content to reduce soil loss and enhance soil water content than other management practices in non-terraced oil palm plantations (Moradi et al. 2012). Moradi et al. (2012) found that oil palm fronds had significantly lower $\mathrm{K}$ and $\mathrm{Mg}$ but higher $\mathrm{C}, \mathrm{N}$, and $\mathrm{Ca}$ concentrations than EFB.

\section{Frond pruning}

Pruned oil palm fronds are another form of oil palm waste that is typically used to protect surface soil from direct raindrop impact. Lord and Clay (2006) recommended the 
application of fronds in mitigating sheet and rill erosion to reduce soil loss and assist in the establishment of natural vegetation. This method has been shown by Mohd Ali (1997) to enhance organic matter, aggregate stability and water content in soil, and decrease soil bulk density. The total organic matter in soil is critical in determining the stability of soil aggregates, as the loss of organic matter results in unstable soil structure (Oades 1988). However, Moradi et al. (2012) and Sahat et al. (2016) found that dried fronds are less effective in reducing soil erosion rates than other cover crops, such as grass.

However, oil palm fronds can be used to slow down surface runoff velocity by acting as surface flow breakers. In addition, Lim (1990) found that pruned fronds can decrease erosion rates on slopes of $3^{\circ}$ to $5^{\circ}$ by averting the direct impact of rain drops. The adjustment of the layout position of dried fronds also needs to be considered, as a layout position perpendicular to groundwater surface flows is more effective in preventing soil loss compared to a layout position parallel to groundwater surface flows (Sahat et al. 2016). Even though pruned fronds release high amounts of nutrients, such as $\mathrm{N}, \mathrm{P}, \mathrm{K}$, and $\mathrm{Mg}$, into soil (Husin et al. 1987), they are a less practical solution to reduce soil loss and enhance soil water content than other management practices in non-terraced oil palm plantations (Moradi et al. 2012). Moradi et al. (2012) found that oil palm fronds had significantly lower $\mathrm{K}$ and $\mathrm{Mg}$ but higher $\mathrm{C}, \mathrm{N}$, and $\mathrm{Ca}$ concentrations than $\mathrm{EFB}$.

\section{Eco-mats}

Eco-mats are a recent development using EFB in response to the difficulties in handling this fiber. Eco-mats are a compaction of EFB in the form of a carpet-like material (Yeo 2007) with no chemicals added (Khalid and Tarmizi 2008). Eco-mats are easy to manage, environmentally friendly, and less expensive than EFB mulch (Mohsen et al. 2014). They have been demonstrated to improve the organic matter content, nutrient contents, moisture holding capacity, and structure of soil, and they prevent erosion on slopes (Khalid and Tarmizi 2008). Organic matter stabilizes soil structure by acting as a binding agent that combines mineral particles and creates stable soil aggregates (Tisdall and Oades 1982).

Eco-mats fortify the structure of soil and impede it from erosion, thus creating more favorable circumstances for root growth than bare soil (Khalid and Tarmizi 2008). Ibrahim (2006) discovered that beyond accelerating cover crop growth rate, eco-mats contain N, P, K, C, Mg, and Ca (MPOB 2003; Khalid and Tarmizi 2008). However, Moradi et al. (2012) claimed that eco-mats are not recommended because although they increased bulk density compared to EFB and palm frond, which was probably due to the manufacturing process, eco-mats contain lower nutrient concentrations, water content, porosity, and saturated hydraulic conductivity.

\section{Leguminous cover plants}

Leguminous cover crops, which are established in the inter-row areas of oil palm trees to deter soil erosion (especially in slope areas) are commonly sown during the first 240 to 300 days of land clearing (Wahab 2001; Turner and Gillbanks 2003). Legume cover crops, such as Mucuna bracteata, Calopogonium mucunoides, Axonopus compressus, and Pueraria phaseoloides, are cultivated to cover and shield the soil from weeds or plants. $M$. bracteata is a fast-growing plant that grows about $10 \mathrm{~cm}$ to $15 \mathrm{~cm}$ per day and is suitable for soil conservation purposes, as it has been proven to decrease soil loss and retain soil moisture better than other surface types, such as bare soil, half grass cover, and half dry frond (Sahat et al. 2016). A. compressus was reported to grow faster than M. bracteata, 
which took 6 months to provide a dense vegetative growth, whereas A. compressus provides such vegetative growth within 3 months, making it the most suitable cover crop candidate for oil palm plantations (Samedani et al. 2015).

Beyond the advantageous effects of legume cover on maintaining soil structure, the physical and chemical characteristics of soil and soil fertility are also improved (Watson et al. 2002). Through reducing erosion and runoff, cover crops prevent water resources from being contaminated by nonpoint source pollution caused by the washing off of sediments (Clark 2010). Permanent cover crops reduce erosion risk and consequently maintain soil nutrient and organic matter content, and they improve soil structure (Lal et al. 1991). Khalid et al. (2000) performed a comparison study between legumes, weeds, and litter (mixture of legumes and weeds) in an 18-month-old oil palm area and discovered that legumes contribute a relatively high amount of total nutrients (e.g., N, P, K, Ca, and $\mathrm{Mg}$ ) in soil. This was in agreement with Szott (1987) and Lehmann et al. (2000). However, nutrient competition between cover crops and oil palm trees may occur, which reduces palm oil production. If climber legumes are used as a cover crop, comprehensive plant nursery management is needed to prevent them from smothering the tree crops (Watson 1989; Samedani et al. 2015).

\section{Limitations of "Green" Resources in Soil Stabilizer}

Although natural polymers have enormous advantages regarding environmental issues, there are some limitations to dealing with these polymers. The main concern in using natural fibers to reinforce soil is the loss of tensile strength with time, which is usually due to physical, biological, or chemical effects or their combined action (Kugan and Sarsby 2011). In addition, unlike synthetic polymers, the mechanical properties of vegetable fibers tend to change based on various factors, such as source, age, species, chemical constituents, and internal structure (Satyanarayana et al. 1986).

\section{EFB-SEAWEED COMPOSITE IN SOIL STABILIZER APPLICATIONS}

Fundamentally, vegetation plays a significant role in the natural mitigation of soil erosion. However, human alteration (land clearing) and environmental consequences (climate change) have had tremendous impacts on geomorphological process and accelerated soil erosion, which results in sedimentation. Sedimentation increases the vulnerability of watersheds to natural flood disasters (Lee et al. 2012; Syakir et al. 2016; Zafirah et al. 2016). Therefore, natural fibers are a promising biomaterial in mitigating soil erosion due to their potential role in promoting water circulation within the soil profile (Guerra et al. 2015). The fundamental mechanisms of fiber-soil interaction are critical in understanding the infiltration capacity of a particular degraded soil system.

\section{Interaction of Soil and EFB-seaweed Composite}

Flood initiation phenomena are presented in Fig. 1. The roles of EFB-seaweed composites in reducing the impacts of raindrops during the sheet or rill erosion stage are also illustrated in Fig. 1. Bare soil (at the right side of Fig. 1) is exposed to the impact of rain drops, which causes soil particles to disintegrate and disaggregate into fine particles. The absence of organic matter and exchangeable cations worsens the situation, as the loss of both are closely related to decreased soil aggregate stability (Oades 1988). The soil particle disintegration process weakens the interparticle attractive force, which deteriorates 
the soil structure. The disaggregation mechanism causes fine particles to spread out in all directions up to a distance of $1 \mathrm{~m}$, clogging the soil pores. These clogged pores create a surface seal, which increases soil impermeability and consequently impedes the infiltration of water into the soil system. This results in a high volume of surface run off and soil erosion.

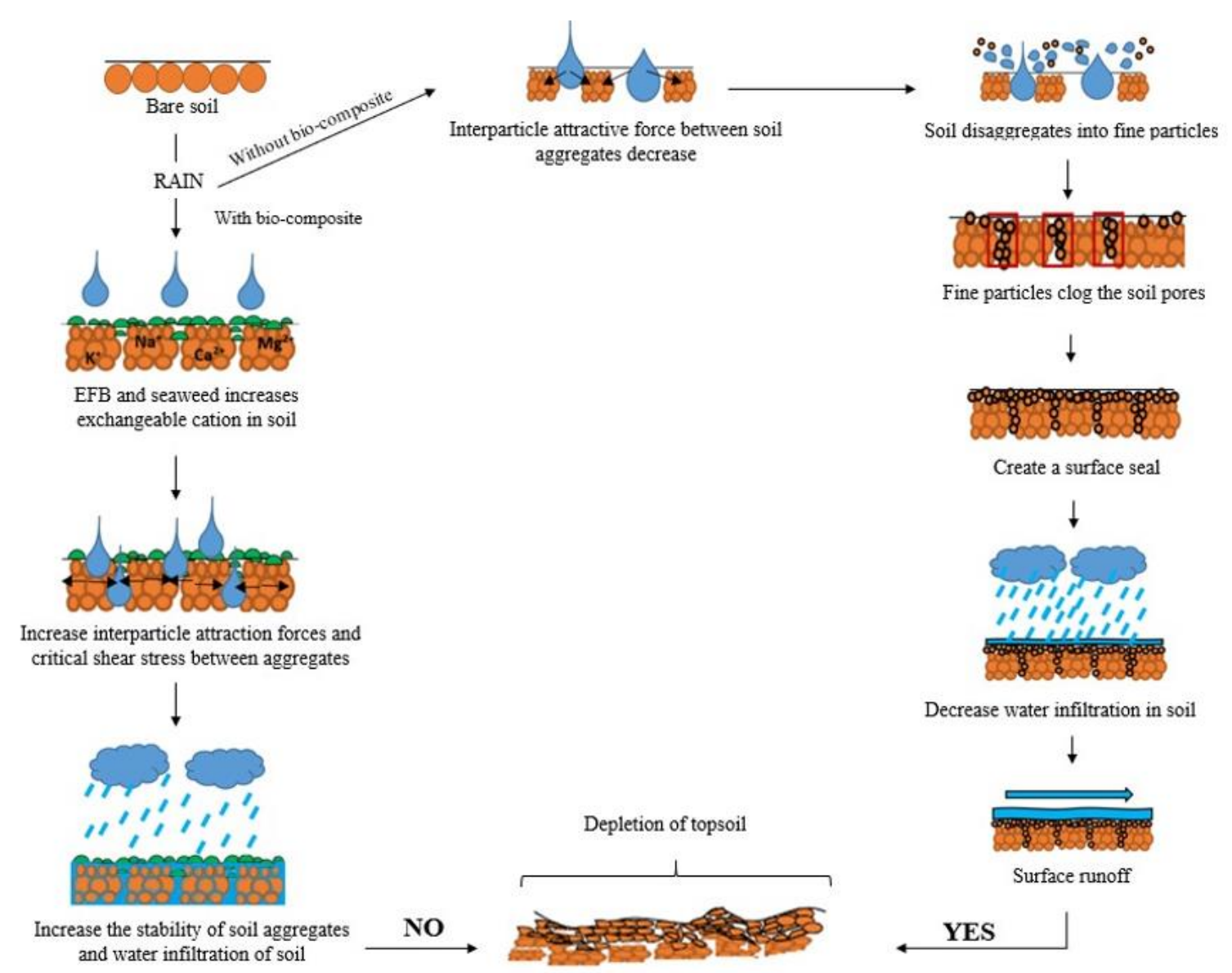

Fig. 1. The role of biodegradable materials in controlling soil erosion

In contrast, bare soil covered with RBP (OPEFB-seaweed) (shown on the left side of Fig. 1) increases the interparticle attraction force between soil particles. The presence of ions in seaweed contributes to the increase of exchangeable cations in soil, thus improving the soil structure and soil fertility. Increasing the organic matter and exchangeable cations in the soil improves the stability of soil, as they act as a binding agent that enhances the stability of aggregates (Tisdall and Oades 1982; Haynes et al. 1991; Shepherd et al. 2001). The increase of interparticle attraction forces increases the critical shear stress between soil particles, which makes it difficult for raindrops to break these particles and disaggregate them into fine particles. This increases the infiltration of water into soil and reduces surface run off and soil erosion.

Understanding the mechanism of the interaction between the biodegradable composite with the degraded soil system is critical in increasing soil infiltration capacity. Stable interparticle attraction increases the critical shear stress between soil particles, which results in high resistance of the soil system to raindrop impacts, thus reducing surface runoff and soil erosion. Further, the selected matrix (seaweed) has a high ion 
content, which complements the binding properties of the composite and improves soil fertility (Nurin et al. 2016). Such an understanding provides allows the implementation of prevention measures at early states of erosion (i.e., the development of sheet-type erosion), thus lowering the risks of natural hazards.

\section{Importance of EFB-seaweed Composite as a Soil Stabilizer}

The hydrophilic characteristics of biodegradable materials demonstrate high potential in absorbing raindrop impacts and retaining water, and they subsequentlyrelease the water into the soil as the material gradually degrades after a certain time period (Syakir et al. 2016). Such a mechanism stabilizes the degraded soil system, which improves its water circulation process. Remarkably, the unique hydrophilic characteristics of these natural fibers plays a significant role in absorbing raindrop impacts and retaining and releasing the water in a gradual fashion upon degradation (Syakir et al. 2016).

Unlike other erosion control materials, such as mulches and geotextiles, which need to be applied manually onto the soil, the pellet-shaped EFB-seaweed composite does not fully rely on manual labor. Instead, machines, such as tractor fertilizer spreaders, can be used to disperse this biocomposite onto potential areas. At the decomposition phase, natural fibers that contain distinctive nutrients (Nurin et al. 2016) are essential for soil fertility and plant growth (Syakir et al. 2016). In this case, seaweed is an option for the matrix (Nurin et al. 2016) and is part of the biocomposite-soil interaction mechanism studies due to its beneficial element content, which is essential for soil fertility and plant growth.

\section{Challenges and Limitations of EFB-seaweed as a Soil Stabilizer}

Although EFB-seaweed composites have high potential for reducing soil run-off and improving the water circulation system, there are some limitations and challenges for the application of this biocomposite. Firstly, the proportions of EFB and seaweed in the composite have yet to be determined. This factor plays a vital role in defining the mechanical properties of a biocomposite. Incorrect proportions can lead to micro cracks on the surface of the composite, thus affecting its performance during application. Secondly, the EFB-seaweed composite seems to be limited for application on areas with less than $25^{\circ}$ slope. At the early stage of studying this composite, attention was only given to the physical and mechanical characteristics of the EFB-seaweed composite (water absorption, impact strength, etc.). In addition, "anchor" behavior was considered to ensure that the biocomposite could be rooted to the ground during application.

\section{Future Perspective}

The application of abundance natural fiber from agriculture waste in composites has great potential for use as a soil stabilizer due its natural hydrophilic characteristics. Such green composites can be developed at lower cost by blending the matrix with abundant materials, such sludge, polylactide and thermo plastic starch. This review was inspired by the exploration of new waste management initiatives, which can be potentially mobilized by the leading agriculture companies to restore degraded soil systems in plantation areas. Such optimization of waste resources will also benefit the economy of the agricultural industry in the long run.

The capacity of the studied biocomposite to retain significant amounts of water and increase water circulation in the soil system is critical to the improvement of soil fertility 
and productivity, particularly in plantation areas. Its special characteristics are promising for cost effective and sustainable management of plantations, especially in tropical regions that are subjected to an abundance of rainfall. In addition, such an understanding will open new perspectives of waste recovery (instead of waste recycling) in the agricultural industry. This is where the industry can contribute to sustainability to for ecosystem conservation.

\section{CONCLUSION}

Exploration of plant-based fibers has continued to develop due to the growing interest in the sustainable use of crude materials due to the low cost, low density, strength, and local availability of these fibers. Among natural fibers, jute is commonly selected by many authors for controlling soil erosion due to its hydroscopic and superior mechanical properties. Researchers have confirmed that establishing ground cover is more critical for soil protection compared to the type of material chosen for erosion mitigation. Reviews from past studies showed that the research on biocomposites in controlling soil erosion is limited compared to the research on natural fibers used for the same purpose. This is perhaps due to the poor availability and high cost of biodegradable polymers compared to natural fibers, which are abundant and inexpensive. Poor adhesive interactions between the matrix and natural fibers due to the hydrophilic characteristic of the fibers is another major drawback that sometimes limits the development of biocomposites for controlling soil erosion.

\section{ACKNOWLEDGEMENTS}

The authors gratefully acknowledge the financial aid provided from Universiti Sains Malaysia, Penang (Grant No. 304.PTEKIND.6316496). The authors thank all those that were directly and indirectly involved in finishing this manuscript.

\section{REFERENCES CITED}

Abdullah, N., and Sulaiman, F. (2013). "The oil palm wastes in Malaysia," in: Biomass Now: Sustainable Growth and Use, M. D. Matovic (ed.), Intech, Rijeka, Croatia, pp. 75-93.

Abu Bakar, R., Darus, S. Z., Kulaseharan, S., and Jamaluddin, N. (2011). "Effects of ten years' application of empty fruit bunches in an oil palm plantation on soil chemical properties," Nutrient Cycling in Agroecosystems 89(3), 341-349. DOI:

10.1007/s10705-010-9398-9

Adekalu, K., Olorunfemi, I., and Osunbitan, J. (2007). "Grass mulching effect in infiltration, surface runoff and soil loss of three agricultural soils in Nigeria," Bioresource Technology 98(4), 912-917. DOI: 10.1016/j.biortech.2006.02.044

Agassi, M., Hadas, A., Benyamini, Y., Levy, G. J., Kautsky, L., Avrahamov, L., and Zhevelev, H. (1998). "Mulching effects of composted MSW on water percolation and compost degradation rate," Compost Science \& Utilization 6(3), 34-41. DOI: 10.1080/1065657X.1998.10701929 
Aggarwal, P., and Sharma, B. (2010). "Application of jute fiber in the improvement of subgrade characteristics," in: Proceedings of the International Conference on Advances in Civil Engineering, Kerala, India, pp. 51-53.

Agrawal, B. J. (2011). "Geotextile: Its application to civil engineering - Overview," in: Proceedings of the National Conference on Recent Trends in Engineering \& Technology, Gujarat, India, pp. 1-6.

Ahmad, F. B., Zhang, Z., Doherty, W. O. S., and O'Hara, I. M. (2016). "Evaluation of oil production from oil palm empty fruit bunch by oleaginous micro-organisms," Biofuels, Bioproducts and Biorefining 10(4), 378-392. DOI: 10.1002/bbb.1645

Alam, A. (1998). "Retting and extraction of jute problems and prospects," in: Proceedings of International Seminar on Jute and Allied Fibres/Changing Global Scenario, Calcutta, India, pp. 5-6.

Alam, M. Z., Muyibi, S. A., Mansor, M. F., and Wahid, R. (2007). “Activated carbons derived from oil palm empty-fruit bunches: Application to environmental problems," Journal of Environmental Sciences 19(1), 103-108. DOI: 10.1016/S10010742(07)60017-5

Alavez-Ramirez, R., Montes-Garcia, P., Martínez-Reyes, J., Altamirano-Juárez, D. C., and Gochi-Ponce, Y. (2012). "The use of sugarcane bagasse ash and lime to improve the durability and mechanical properties of compacted soil blocks," Construction and Building Materials 34, 296-305.

Ahn, T., Cho, S., and Yang, S. (2002). "Stabilization of soil slope using geosynthetic mulching mat," Geotextiles and Geomembranes 20(2), 135-146. DOI: 10.1016/s0266-1144(02)00002-X

Akil, H. M., Omar, M. F., Mazuki, A. A. M., Safiee, S., Ishak, Z. A. M., and Abu Bakar, A. (2011). "Kenaf fiber reinforced composites: A review," Materials \& Design 32(8-9), 4107-4121. DOI: 10.1016/j.matdes.2011.04.008

Androff, N. W., Francis, L. F., and Velamakanni, B. V. (1997). "Macroporous ceramics from ceramic-polymer dispersion methods," AIChE Journal 43(S11), 2878-2888. DOI: 10.1002/aic.690431339

Arif, S., Goh, K. J., and Teo, C. H. (2003). "Temporal soil moisture contents on hilly slope under oil palm as influenced by soil conservation practices," in: Proceedings of the Malaysian Society Soil Science Conference 2003, Kuala Lumpur, Malaysia, pp. 133-141.

Ashikin, N. S. S. N., Djalaluddin, A., Yusuff, S., Khalil, H. A., \& Syakir, M. I. (2019). Empty fruit bunch-seaweed biocomposite as potential soil erosion mitigation material for oil palm plantation. BioResources, 14(3), 5438-5450.

Artidteang, S., Bergado, D. T., Tanchaisawat, T., and Saowapakpiboon, J. (2012). "Investigation of tensile and soil-geotextile interface strength of kenaf woven limited life geotextiles (LLGS)," Lowland Technology International 14(2), 1-8.

Avérous, L., and Boquillon, N. (2004). "Biocomposites based on plasticized starch: Thermal and mechanical behaviours," Carbohydrate Polymers 56(2), 111-122. DOI: 10.1016/j.carbpol.2003.11.015

Avérous, L., and Halley, P. J. (2009). "Biocomposites based on plasticized starch," Biofuels, Bioproducts and Biorefining 3(3), 329-343. DOI: 10.1002/bbb.135

Banik, S., Basak, M., Paul, D., Nayak, P., Sardar, D., Sil, S. C, Sanpui, B. C., and Ghosh, A. (2003). "Ribbon retting of jute-a prospective and eco-friendly method for improvement of fibre quality," Industrial Crops and Products 17(3), 183-190. DOI: 10.1016/s0926-6690(02)00097-3 
Barooah, A. K., and Goswami, H. (1997). "Biodegradable jute geotextile for integrated soil and crop management in Tea-Part 1: Soil conservation," in: Proceedings of Workshop on Jute Geotextile, IJMAJMDC, Kolkata, India.

Barton, J., Niemczyk, A., Czaja, K., Korach, L., and Sachermajewska, B. (2014). "Polymer composites, biocomposites and nanocomposites. Production, composition, properties and application fields," Chemik 68(4), 280-287.

Basiron, Y. (2007). "Palm oil production through sustainable plantations," European Journal of Lipid Science and Technology 109(4), 289-295.

DOI:10.1002/ejlt.200600223

Bastioli, C. (1998). "Biodegradable materials - Present situation and future perspectives," Macromolecular Symposia 135(1), 193-204. DOI: 10.1002/masy.19981350122

Batra, S. K. (1985). "Other long vegetable fibers," in: Handbook of Fibre Chemistry, M. Lewin, and E. M. Pearce (eds.), Marcel Dekker, New York, NY, USA, pp. 505-575.

Borst, H. L., and Mederski, H. J. (1957). "Surface mulches and mulch tillage for corn production," Ohio Agricultural Experiment Station Research Bulletin 796, 1-19.

Burgueño, R., Quagliata, M. J., Mohanty, A. K., Mehta, G., Drzal, L. T., and Misra, M. (2004). "Load-bearing natural fiber composite cellular beams and panels," Composites Part A: Applied Science and Manufacturing 35(6), 645-656. DOI: 10.1016/j.compositesa.2004.02.012

Cerdà, A., and Doerr, S. H. (2008). "The effect of ash and needle cover on surface runoff and erosion in the immediate post-fire period," Catena 74(3), 256-263. DOI: 10.1016/j.catena.2008.03.010

California Stormwater Quality Association (2003). BMP Handbook. Construction, State of California, Department of Transportation, Sacramento, CA, USA.

Carvalho, J. L. N., Otto, R., Franco, H. C. J., and Trivelin, P. C. O. (2013). "Input of sugarcane post-harvest residues into the soil," Scientia Agricola 70(5), 336-344. DOI:10.1590/S0103-90162013000500008

Cheung, H., Ho, M., Lau, K., Cardona, F., and Hui, D. (2009). "Natural fibre-reinforced composites for bioengineering and environmental engineering applications," Composites Part B: Engineering 40(7), 655-663. DOI: 10.1016/j.compositesb.2009.04.014

Chiesa, S., and Gnansounou, E. (2014). "Use of empty fruit bunches from the oil palm for bioethanol production: A thorough comparison between dilute acid and dilute alkali pretreatment," Bioresource Technology 159, 355-364. DOI: 10.1016/j.biortech.2014.02.122

Choudhury, P. K., and Sanyal, T. (2010). "Embankment slope stabilization with jute geotextiles - A case study in NH-2 Allahabad bypass," in: Proceedings of the 2010 Indian Geotechnical Conference, Mumbai, India, pp. 731-734.

Clark, A. (2010). Managing Cover Crops Profitably, Sustainable Agriculture Research \& Education, College Park, MD, USA.

Clay, J. (2004). "Palm oil," in: World Agriculture and the Environment: A Commodity by Commodity Guide to Impacts and Practices, Island Press, Washington, DC, USA, pp. 203-235.

Collier, J. R., Collier, B. J., Thames, J. L., and Elsumi, M. M. (1997). "Production and evaluation of sugarcane fiber geotextiles, Report 2: Field testing, Louisiana Transportation Research Center, Baton Rouge, LA, USA.

Comte, I., Colin, F., Grünberger, O., Follain, S., Whalen, J. K., and Caliman, J.-P. (2013). "Landscape-scale assessment of soil response to long-term organic and mineral 
fertilizer application in an industrial oil palm plantation, Indonesia," Agriculture, Ecosystems \& Environment 169, 58-68. DOI: 10.1016/j.agee.2013.02.010

Curvelo, A., De Carvalhoa, A. J. F., and Agnelli, J. A. M. (2001). "Thermoplastic starchcellulosic fibers composites: Preliminary results," Carbohydrate Polymers 45(2), 183-188. DOI: 10.1016/s0144-8617(00)00314-3

Dang, L. C., Fatahi, B., and Khabbaz, H. (2016). "Behaviour of expansive soils stabilized with hydrated lime and bagasse fibres," Procedia Engineering 143, 658-665. DOI: 10.1016/j.proeng.2016.06.093

Datta, U. (2007). “Application of jute geotextiles," Journal of Natural Fibers 4(3), 67-82. DOI: 10.1300/J395v04n03_05

Department of Natural Resources and Water (2006). "Gully erosion [Fact sheet]," Queensland Government, (https://www.qld.gov.au/dsiti/assets/soil/gully erosion.pdf), Accessed 21 May 2020.

Deshmukh, A., Sikdar, P., and Sahu, A. (2015). "A study on erosion control blankets made of rice straw," in: National Conference on Knowledge, Innovation in Technology and Engineering (NCKITE), Raipur, India, pp. 408-409.

Dickey, E. C., Shelton, D. P., Jasa, P. J., and Peterson, T. R. (1985). "Soil erosion from tillage systems used in soybean and corn residues," Transactions of the ASAE 28(4), 1124-1130. DOI: 10.13031/2013.32399

Dittenber, D. B., and Gangarao, H. V. (2012). "Critical review of recent publications on use of natural composites in infrastructure," Composites Part A: Applied Science and Manufacturing 43(8), 1419-1429. DOI: 10.1016/j.compositesa.2011.11.019

Dinu, I. (2006). Erosion Control Products from Sugarcane Bagasse, Master's Thesis, Alexandru Ioan Cuza University, Iasi, Romania.

Dourado-Neto, D., Timm, L. C., De Oliveira, J. C. M., Reichardt, K., Bacchi, O. O. S., Tominaga, T. T., and Cássaro, F. A. M. (1999). "State-space approach for the analysis of soil water content and temperature in a sugarcane crop," Scientia Agricola 56(4), 1215-1221. DOI: 10.1590/s0103-90161999000500025

Edeerozey, A. M., Akil, H. M., Azhar, A. B., and Ariffin, M. I. Z. (2007). "Chemical modification of kenaf fibers," Materials Letters 61(10), 2023-2025. DOI: 10.1016/j.matlet.2006.08.006

Elloumi, A., Makhlouf, M., Elleuchi, A., and Bradai, C. (2016). "The potential of deinking paper sludge for recycled HDPE reinforcement," Polymer Composites 39(3), 616-623. DOI: 10.1002/pc.23975

Farma, R., Deraman, M., Awitdrus, A., Talib, I. A., Taer, E., Basri, N. H., Manjunatha, J. G., Ishak, M. M., Dollah, B. N. M., and Hashmi, S. A. (2013). "Preparation of highly porous binderless activated carbon electrodes from fibres of oil palm empty fruit bunches for application in supercapacitors," Bioresource Technology 132, 254-261. DOI: 10.1016/j.biortech.2013.01.044

Faruk, O., Bledzki, A. K., Fink, H. P., and Sain, M. (2014). "Progress report on natural fiber reinforced composites," Macromolecular Materials and Engineering 299(1), 926.

Feng, D., Caulfield, D. F., and Sanadi, A. R. (2001). "Effect of compatibilizer on the structure-property relationships of kenaf-fiber/polypropylene composites," Polymer Composites 22(4), 506-517. DOI: 10.1002/pc.10555

Fernández, C., and Vega, J. A. (2016). "Are erosion barriers and straw mulching effective for controlling soil erosion after a high severity wildfire in NW Spain?," Ecological Engineering 87, 132-138. DOI: 10.1016/j.ecoleng.2015.11.047 
Fernández-Fernández, M., Vieites-Blanco, C., Gómez-Rey, M. X., and González-Prieto, S. J. (2016). "Straw mulching is not always a useful post-fire stabilization technique for reducing soil erosion," Geoderma 284, 122-131. DOI:

10.1016/j.geoderma.2016.09.001

Flanagan, D. C., Chaudhari, K., and Norton, L. D. (2002). "Polyacrylamide soil amendment effects on runoff and sediment yield on steep slopes: Part II. Natural rainfall conditions," Transactions of the ASAE 45(5), 1339-1351. DOI: $10.13031 / 2013.11070$

Foltz, R. B., and Dooley, J. H. (2003). "Comparison of erosion reduction between wood strands and agricultural straw," Transactions of the ASAE 46(5), 1389-1396. DOI: $10.13031 / 2013.15450$

Foltz, R. B., and Copeland, N. S. (2009). "Evaluating the efficacy of wood shreds for mitigating erosion," Journal of Environmental Management 90(2), 779-785.

Foltz, R. B., and Wagenbrenner, N. S. (2010). "An evaluation of three wood shred blends for post-fire erosion control using indoor simulated rain events on small plots," CATENA 80(2), 86-94. DOI: 10.1016/j.catena.2009.09.003

Forssell, P. M., Mikkila, J. M., and Moates, G. K. (1997). "Phase and glass transition behaviour of concentrated barley starch-glycerol-water mixtures, a model for thermoplastic starch," Carbohydrate Polymers 34(4), 275-282. DOI: 10.1016/S01448617(97)00133-1

Fortes, C., Trivelin, P. C. O., and Vitti, A. C. (2012). "Long-term decomposition of sugarcane harvest residues in Sao Paulo state, Brazil," Biomass and Bioenergy 42, 189-198. DOI: 10.1016/j.biombioe.2012.03.011

Frazão, L. A., Paustian, K., Cerri, C. E. P., and Cerri, C. C. (2014). "Soil carbon stocks under oil palm plantations in Bahia State, Brazil," Biomass and Bioenergy 62, 1-7. DOI: 10.1016/j.biombioe.2014.01.031

Fuad, M. Y. A., Zaini, M. J., Jamaludin, M., and Ridzuan, R. (1994). "Filler-content determination of wood-based composites by thermogravimetric analysis," Polymer Testing 13(1), 15-24. DOI: 10.1016/0142-9418(94)90036-1

Gholami, L., Sadeghi, S. H., and Homaee, M. (2013). "Straw mulching effect on splash erosion, runoff, and sediment yield from eroded plots," Soil Science Society of America Journal 77(1), 268-278. DOI: 10.2136/sssaj2012.0271

Gholami, L., Banasik, K., Sadeghi, S. H., Darvishan, A. K., and Hejduk, L. (2014). "Effectiveness of straw mulch on infiltration, splash erosion, runoff and sediment in laboratory conditions," Journal of Water and Land Development 22(1), 51-60. DOI: 10.2478/jwld-2014-0022

Ghosh, M., Choudhury, P. K., and Sanyal, T. (2009). "Suitability of natural fibres in geotextile applications," in: Proceedings of the Indian Geotechnical Conference 2009, Guntur, India, pp. 497-501.

Ghosh, B., Ramesh, V., and Vibhuti, R. B. (2014). "Improvement of soil characteristics using jute geo-textile," International Journal of Science, Engineering and Technology Research 3(7), 1983-1986.

Gilley, J. E., Finkner, S. C., Spomer, R. G., and Mielke, L. N. (1986). "Runoff and erosion as affected by corn residue: Part I. Total losses," Transactions of the ASAE 29(1), 0157-0160. DOI: 10.13031/2013.30119

Giridhar, J., K., and Rao, R. M. V. G. K. (1986). "Moisture absorption characteristics of natural fibre composites," Journal of Reinforced Plastics and Composites 5(2), 141150. DOI: $10.1177 / 073168448600500205$ 
Gon, D., Das, K., Paul, P., and Maity, S. (2012). "Jute composites as wood substitute," International Journal of Textile Science 1(6), 84-93. DOI: 10.5923/j.textile.20120106.05

Govers, G., and Poesen, J. (1988). "Assessment of the interrill and rill contributions to total soil loss from an upland field plot," Geomorphology 1(4), 343-354. DOI: $10.1016 / 0169-555 \times(88) 90006-2$

Graham, M. H., Haynes, R. J., and Meyer, J. H. (2002). "Changes in soil chemistry and aggregate stability induced by fertilizer applications, burning and trash retention on a long-term sugarcane experiment in South Africa," European Journal of Soil Science 53(4), 589-598. DOI: 10.1046/j.1365-2389.2002.00472.x

Green, D., Kruger, E. L., and Stanosz, G. R. (2003). "Effects of polyethylene mulch in a short-rotation, poplar plantation vary with weed-control strategies, site quality and clone," Forest Ecology and Management 173(1-3), 251-260. DOI: 10.1016/s03781127(02)00003-8

Gupta, P. C. D., Sardar, D., and Majumdar, A. K. (1976). "Chemical retting of jute," Food Farming and Agriculture 8, 7-9.

Gupta, A. K. (1991). “Geotextiles: Opportunities for natural-fibre products,” in: International Trade Forum (Vol. 27, No. 1, p. 10). International Trade Centre.

Hamdan, A. B., Tarmizi, A. M., and Mohd, T. D. (1998). "Empty fruit bunch mulching and nitrogen fertilizer amendment: The resultant on oil palm performance and soil properties," PORIM Bulletin 37, 1-14.

Hamid, A., and Shafiq, H. (2017). "Subgrade soil stabilization using jute fibre as a reinforcing material," International Journal of Engineering Development and Research 5(1), 74-80.

Hartemink, A. E. (2006). "Soil erosion: Perennial crop plantations," in: Encyclopedia of Soil Science, Second Edition, R. Lal (ed.), CRC Press, Boca Raton, FL, USA, pp 1613-1617.

Hättenschwiler, S., Tiunov, A. V., and Scheu, S. (2005). "Biodiversity and litter decomposition in terrestrial ecosystems," Annual Review of Ecology, Evolution, and Systematics 36, 191-218. DOI: 10.1146/annurev.ecolsys.36.112904.151932

Haynes, R. J., Swift, R. S., and Stephen, R. C. (1991). "Influence of mixed cropping rotations (pasture-arable) on organic matter content, water stable aggregation and clod porosity in a group of soils," Soil and Tillage Research 19(1), 77-87. DOI: 10.1016/0167-1987(91)90111-a

Haywood, J. D. (1999). "Durability of selected mulches, their ability to control weeds, and influence growth of loblolly pine seedlings," New Forests 18, 263-276. DOI: 10.1023/A:1006699910149

Herrmann, A., Nickel, J., and Riedel, U. (1998). “Construction materials based upon biologically renewable resources - from components to finished parts," Polymer Degradation and Stability 59(1-3), 251-261. DOI: 10.1016/s0141-3910(97)00169-9

Hoong, H. W., and Nadarajah, M. N. (1988). "Mulching of empty fruit bunches (EFB) of oil palm," Proceedings of the SLDB/PORIM Workshop on Oil Palm Milling Technology, Kuala Lumpur, Malaysia, pp. 38-50.

Huang, J., Shetty, A. S., and Wang, M. (1990). "Biodegradable plastics: A review," Advances in Polymer Technology 10(1), 23-30. DOI: 10.1002/adv.1990.060100103

Husin, M., Zakaria, Z. Z., and Hassan, A. H. (1987). "Potentials of oil palm by-products as raw materials for agro-based industries," in: Proceedings of the 1985 PORIM National Symposium on Oil Palm By-products for Agro-Based Industries, Kuala 
Lumpur, Malaysia, pp. 7-15.

Husin, M., Ramli, R., Mokhtar, A., Wan, W.-H., Hassan, K., Mamat, R., and Aziz, A. A. (2002). "Research and development of oil palm biomass utilization in wood-based industries," Palm Oil Developments 36, 1-5.

Hutmacher, A., Staff, P., and Smith, M. (2015). "The many incredible applications of industrialized hemp," PotGuide, (https://www.coloradopotguide.com/coloradomarijuana-blog/2015/september/16/the-many-incredible-applications-ofindustrialized-hemp/), Accessed 04 June 2017.

Ibrahim, R. (2003). "Structural, mechanical and optical properties of recycled paper blended with oil palm empty fruit bunch pulp," Journal of Oil Palm Research 15(2), 28-34.

Ibrahim, W. A. (2006). Optimization of Mulch Mat Production from Oil Palm Empty Fruit Bunches and Its Effects on Growth Performance of Acacia Hybrid Seedlings on Sandy Tailings, Doctoral Dissertation, Universiti Putra Malaysia, Seri Kembangan, Malayisia.

Ibrahim, Z., Aziz, A. A., Ramli, R., Mokhtar, A., Omar, R., and Lee, S. (2014). "Production of medium density fibreboard (MDF) from oil palm trunk (OPT)," Journal of Applied Sciences 14(11), 1174-1179. DOI: 10.3923/jas.2014.1174.1179

Indonesia Investments (2016). "Palm oil," Indonesia Investments, (https://www.indonesia-investments.com/business/commodities/palm-oil/item166?), Accessed 17 May 2017.

Ingold, T. S., and Thomson, J. C. (1990). "A design approach for performed erosion control systems," in: Proceedings of the $4^{\text {th }}$ International Conference on Geotextiles, Geomembranes and Related Products, Hague, Netherlands, pp. 375-380.

Ingunza, D., Pilar, M. D., Dantas, L. A., and Maribondo, N. R. (2015). "Use of sewage sludge as raw material in the manufacture of roofs," in: Proceedings of the $2^{\text {nd }}$ International Conference on Civil, Materials and Environmental Sciences, Vancouver, Canada, pp. 31-33.

Islam, M. S., Nasrin, S., Islam, M. S., and Moury, F. R. (2013). "Use of vegetation and geo-jute in erosion control of slopes in a sub-tropical climate," International Journal of Civil, Environmental, Structural, Construction, and Architectural Engineering 7(1), 54-62.

Ismail, W. R. (1997). "The impact of hill land clearance and urbanization on runoff and sediment yield of small catchments in Pulau Pinang, Malaysia," in: Proceedings of Rabat Symposium S6, Rabat, Morocco, pp. 279.

Isrealsen, C. E., and Urroz, G. (1990). "Product evaluation for soil erosion control and plant growth enhancement," Report No. 352, Utah Water Research Laboratory, Logan, UT, USA.

Izani, M. A. N., Paridah, M. T., Anwar, U. M. K., Nor, M. Y. M., and H'Ng, P. S. (2013). "Effects of fiber treatment on morphology, tensile and thermogravimetric analysis of oil palm empty fruit bunches fibers," Composites Part B: Engineering 45(1), 12511257. DOI: 10.1016/j.compositesb.2012.07.027

Kim, K.-W., Lee, B.-H., Kim, S., Kim, H.-J., Yun, J.-H., Yoo, S.-E., and Sohn, J. R. (2011). "Reduction of VOC emission from natural flours filled biodegradable biocomposites for automobile interior," Journal of Hazardous Materials 187(1-3), 37-43. DOI: 10.1016/j.jhazmat.2010.07.075

Jabran, K. (2019). Role of Mulching in Pest Management and Agricultural Sustainability, Cham: Springer. 
Jackson, J. A. (1997). Glossary of Geology, $4^{\text {th }}$ Edition, American Geological Institute, Alexandra, VA, USA.

Jadvani, R. H., and Gandhi, K. S. (2013). "Geosynthetics, a versetile solution to challenges in geotechnical engineering," International Journal of Research in Engineering and Technology 2(8), 194-201. DOI: 10.15623/ijret.2013.0208033

Jahan, M. S., Rahman, J. N., Islam, M., and Quaiyyum, M. (2016). "Chemical characteristics of ribbon retted jute and its effect on pulping and papermaking properties," Industrial Crops and Products 84, 116-120. DOI:

10.1016/j.indcrop.2016.01.054

Jirawattanasomkul, T., Ueda, T., Likitlersuang, S., Zhang, D., Hanwiboonwat, N., Wuttiwannasak, N., and Horsangchai K. (2019). "Effect of natural fibre reinforced polymers on confined compressive strength of concrete," Construction and Building Materials 223, 156-164. DOI:10.1016/j.conbuildmat.2019.06.217

Johansen, M. P., Hakonson, T. E., and Breshears, D. D. (2001). "Post-fire runoff and erosion from rainfall simulation: Contrasting forests with shrublands and grasslands," Hydrological Processes 15(15), 2953-2965. DOI: 10.1002/hyp.384

John, J., Tang, J., and Bhattacharya, M. (1998). "Processing of biodegradable blends of wheat gluten and modified polycaprolactone," Polymer 39(13), 2883-2895. DOI: 10.1016/S0032-3861(97)00553-3

Kaldor, A. F., Karlgren, C., and Verwest, H. (1990). "Kenaf - a fast growing fiber source for papermaking," TAPPI Journal 73(11), 205-209.

Karina, M., Onggo, H., Dawam Abdullah, A., and Syampurwadi, A. (2008). "Effect of oil palm empty fruit bunch fiber on the physical and mechanical properties of fiber glass reinforced polyester resin," Journal of Biological Sciences 8(1), 101-106. DOI: 10.3923/jbs.2008.101.106

Karus, M., Kaup, M., and Lohmeyer, D. (2000). "Study on markets and prices for natural fibres (Germany and EU)," in: Proceedings of the $3^{\text {rd }}$ International Symposium Bioresource Hemp \& Other Fibre Crops, Wolfsburg, Germany.

Khalid, H., Zakaria, Z. Z., and Anderson, J. M. (2000). "Soil nutrient dynamics and palm growth performance in relation to residue management practices following replanting of oil palm plantations," Journal Oil Palm Research 12(1), 25-45.

Khalid, H., and Tarmizi, A. (2008). "Techniques of soil and water conservation and nutrient recycling in oil palm plantations on inland soils," Oil Palm Bulletin 56, 1-11.

Kirby, R. H. (1963). Vegetable Fibres, Leonard Hill Ltd., London, England.

Kugan, R., and Sarsby, R. W. (2011). "In-soil biodegradation of palm mat geotextiles," Land Degradation \& Development 22(5), 463-471. DOI: 10.1002/ldr.1099

Kugler, D. E. (1996). "Kenaf commercialization: 1986-1995," in: Progress in New Crops, J. Janick (ed.), ASHS Press, Alexandria, VA, USA, pp. 129-132.

Kukal, S. S., and Sarkar, M. (2010). "Splash erosion and infiltration in relation to mulching and polyvinyl alcohol application in semi-arid tropics," Archives of Agronomy and Soil Science 56(6), 697-705. DOI: 10.1080/03650340903208871

Kumar, T. K., and Jagan, B. (2016). "A critical review on applications of natural jute fibres a case study," International Journal of Civil Engineering and Technology 7(3), 200-210.

Lal, R., Regnier, E., Eckert, D. J., Edwards, W. M., and Hammond, R. (1991). "Expectations of cover crops for sustainable agriculture. Cover crops for clean water," Hargrove WL Soil and Water Conservation Society publication, Ankey, Iowa, USA, 1-11. 
Lampe, M., and Gazda, G. M. (1995). "Green marketing in Europe and the United States: An evolving business and society interface," International Business Review 4(3), 295312. DOI: 10.1016/0969-5931(95)00011-N

Lattanzi, A. R., Meyer, L.D., and Baumgardner, M. F. (1974). "Influences of mulch rate and slope steepness of an interill erosion," Soil Science Society of America Journal 38(6), 946-950. DOI: 10.2136/sssaj1974.03615995003800060030x

Lauriault, L. M., and Puppala, N. (2009). "The influence of rainfed and limited irrigation conditions and early $v s$. late plantings on kenaf as a potential industrial crop in the southern High Plains, USA," Industrial Crops and Products 29(2-3), 549-553. DOI: 10.1016/j.indcrop.2008.10.006

Lee, S., Won, C. H., Shin, M., Park, W., Choi, Y., Shin, J., and Choi, J. (2012). "Application of surface cover and soil amendment for reduction of soil erosion from sloping field in Korea," in: Proceedings of the International Conference of Agricultural Engineering - CIGR - AgEng 2012: Agriculture and Engineering for Healthier Life, Valencia, Spain, pp. 1-5.

Lehmann, J., Da Silva, J. P., Trujillo, L., and Uguen, K. (2000). "Legume cover crops and nutrient cycling in tropical fruit tree production," Acta Horticulturae 531, 65-72. DOI: $10.17660 /$ actahortic.2000.531.8

Lekha, K. R. (2004). "Field instrumentation and monitoring of soil erosion in coir geotextile stabilised slopes - A case study," Geotextiles and Geomembranes 22(5), 399-413. DOI: 10.1016/j.geotexmem.2003.12.003

Leknoi, U., and Likitlersuang, S. (2020). "Good practice and lesson learned in promoting vetiver as solution for slope stabilisation and erosion control in Thailand," Land Use Policy 99, article no. 105008. DOI:10.1016/j.landusepol.2020.105008

LeMahieu, P. J., Oplinger, E. S., and Putnam, D. H. (1991). "Alternative field crops manual: Kenaf," (https://hort.purdue.edu/newcrop/afcm/kenaf.html), Accessed 21 July 2020.

Leman, Z., Sapuan, S. M., Saifol, A. M., Maleque, M. A., and Ahmad, M. M. H. M. (2008). "Moisture absorption behavior of sugar palm fiber reinforced epoxy composites," Materials \& Design 29(8), 1666-1670. DOI: 10.1016/j.matdes.2007.11.004

Lentz, R. D., and Sojka, R. E. (1994). "Field results using polyacrylamide to manage furrow erosion and infiltration," Soil Science 158(4), 274-282.

Levin, J., Ben-Hur, M., Gal, M., and Levy, G. (1991). "Rain energy and soil amendments effects on infiltration and erosion of three different soil types," Australian Journal of Soil Research 29(3), 455-465. DOI: 10.1071/sr9910455

Levy, G. J., Levin, J., Gal, M., Ben-Hur, M., and Shainberg, I. (1992). "Polymers effects on infiltration and soil erosion during consecutive simulated sprinkler irrigations," Soil Science Society of America Journal 56(3), 902-907. DOI: 10.2136/sssaj1992.03615995005600030037x

Li, Y., Shao, M., and Horton, R. (2011). "Effect of polyacrylamide applications on soil hydraulic characteristics and sediment yield of sloping land," Procedia Environmental Sciences 11(B), 763-773. DOI: 10.1016/j.proenv.2011.12.118

Likitlersuang, S., Kounyou, K., and Prasetyaningtiyas, G. A. (2020). "Performance of geosynthetic cementitious composite mat and vetiver on soil erosion control," Journal of Mountain Science 17(6), 1410-1422. DOI:10.1007/s11629-019-5926-5

Lim, K. H., and Messchalck, G. (1979). "Moisture conservation and distribution in a soil profile through mulching and their effects on some soil properties and yield of cow 
peas," in: Proceedings of the Symposium on Water in Malaysia Agriculture, Kuala Lumpur, Malaysia, pp. 69-87.

Lim, K. H. (1990). "Soil erosion under mature oil palms on slopes," in: Proceedings of the 1989 PORIM International Palm Oil Development Congress - Module II: Agriculture Conference, Bangi, Malaysia, pp. 191-198.

Lim, K. O., Ahmaddin, F. H., and Vizhi, S. M. (1997). "A note on the conversion of oilpalm trunks to glucose via acid hydrolysis," Bioresource Technology 59(1), 33-35. DOI: $10.1016 / \mathrm{s} 0960-8524(96) 00131-9$

Lord, S., and Clay, J. (2006). "Environmental impacts of oil palm - Practical considerations in defining sustainability for impacts on the air, land and water," in: Proceedings of the International Planters Conference on Higher Productivity and Efficient Practices for Sustainable Agriculture, Putrajaya, Malaysia, pp. 26-28.

Luo, S., and Netravali, A. N. (1999). "Mechanical and thermal properties of environment-friendly "green" composites made from pineapple leaf fibers and poly(hydroxybutyrate-co-valerate) resin," Polymer Composites 20(3), 367-378. DOI: 10.1002/pc.10363

Ma, X., Yu, J., and Kennedy, J. F. (2005). "Studies on the properties of natural fibersreinforced thermoplastic starch composites," Carbohydrate Polymers 62(1), 19-24. DOI: 10.1016/j.carbpol.2005.07.015

Maghchiche, A., Haouam, A., and Immirzi, B. (2010). "Use of polymers and biopolymers for water retaining and soil stabilization in arid and semiarid regions," Journal of Taibah University for Science 4(1), 9-16. DOI: 10.1016/s16583655(12)60022-3

Magurno, A. (1999). "Vegetable fibres in automotive interior components," Angew Makromolekulare Chemie Journal 272(1), 99-107. DOI: 10.1002/(SICI)15229505(19991201)272:1<99::AID-APMC99>3.0.CO;2-C

Majumdar, A. K., and Day, A. (1977). "Chemical constituents of jute ribbon and the materials removed by retting," Food Farming and Agriculture 21, 25-26.

Mapa, R. B. (1996). “Coconut fibre: A biodegradable soil erosion control,” Biological Agriculture \& Horticulture 13(2), 149-160. DOI: 10.1080/01448765.1996.9754774

Marsh, G. (2003). "Next step for automotive materials," Materials Today 6(4), 36-43. DOI: $10.1016 / \mathrm{s} 1369-7021(03) 00429-2$

Mathur, S., Nanda, P. K., and Vittal, U. K. G. (2008). "Jute geotextiles - Potential and applications in road works," in: Proceedings of the International Workshop on Jute Geotextiles Technical Potential \& Commercial Prospects, International workshop on jute geotextiles-technical potential and commercial prospects, JMDC, Kolkata, April 2008

May-Pat, A., Valadez-González, A., and Herrera-Franco, P. J. (2013). "Effect of fiber surface treatments on the essential work of fracture of HDPE-continuous henequen fiber-reinforced composites," Polymer Testing 32(6), 1114-1122. DOI: 10.1016/j.polymertesting.2013.06.006

Mati, B. M. (2012). Soil and Water Conservation Structures for Smallholder Agriculture, (Training Manual 5), Nile Equatorial Lakes Subsidiary Action Programme (NELSAP) - Regional Agricultural and Trade Programme (RATP), Bujumbura, Burundi.

Mattone, R. (2005). "Sisal fibre reinforced soil with cement or cactus pulp in bahareque technique," Cement and Concrete Composites 27(5), 611-616. DOI:

10.1016/j.cemconcomp.2004.09.016 
McCullah, J., and Howard, V. (2000). "Shasta College erosion control blanket study," Land and Water Magazine 44(5), 21-25.

Methacanon, P., Weerawatsophon, U., Sumransin, N., Prahsarn, C., and Bergado, D. T. (2010). "Properties and potential application of the selected natural fibers as limited life geotextiles," Carbohydrate Polymers 82(4), 1090-1096. DOI:

10.1016/j.carbpol.2010.06.036

Meyer, L. D., Wischmeier, W. H., and Foster, G. R. (1970). "Mulch rates required for erosion control on steep slopes," Soil Science Society of America Journal 34(6), 928931. DOI: 10.2136/sssaj1970.03615995003400060031x

Miao, C., Ni, J., Borthwick, A. G., and Yang, L. (2011). "A preliminary estimate of human and natural contributions to the changes in water discharge and sediment load in the Yellow River," Global and Planetary Change 76(3-4), 196-205. DOI: 10.1016/j.gloplacha.2011.01.008

Michell, A. J. (1986). “Composites containing wood pulp fibres,” Appita Journal 39(3), 223-229.

Miner, R., and Unwin, J. (1991). "Progress in reducing water use and wastewater loads in the U.S. paper industry," TAPPI Journal 74(8), 127-131.

Mohanty, A. K., Misra, M., and Hinrichsen, G. (2000). "Biofibres, biodegradable polymers and biocomposites: An overview," Macromolecular Materials and Engineering 276-277(1), 1-24. DOI: 10.1002/(SICI)1439-

2054(20000301)276:1<1::AID-MAME1>3.0.CO;2-W

Mohd Ali, A. (1997). Field Decomposition of Oil Palm Frond and Its Effects on Soil Physical Properties, Master's Thesis, Universiti Putra Malaysia, Serdang, Malaysia.

Mohsen, B., Christopher, T. B. S., Husni, M. H. A., and Zaharah, A. R. (2014). "Soil, nutrients and water conservation practices in oil palm plantations on sloping and steep lands in Malaysia," in: Proceedings of the International Agriculture Congress 2014, Putrajaya, Malaysia.

Moradi, A., Christopher, T. B. S., Goh, K. J., Hanif, A. H. M., and Fuziah, C. I. (2012). "Evaluation of four soil conservation practices in a non-terraced oil palm plantation," Agronomy Journal 104(6), 27-40. DOI: 10.2134/agronj2012.0120

Moser, K. (1992). Fiber-reinforced Plastic, VDI-Verlag, Düsseldorf, Germany.

MPOB (2003). Malaysia Palm Oil Board, Consultancy Services on the Use of Mulching Mat, Ecomat, as a Mulch for Young Palm, Malaysian Palm Oil Board, Bangi, Malaysia.

Muñoz, K., Buchmann, C., Meyer, M., Schmidt-Heydt, M., Steinmetz, Z., Diehl, D., Thiele-Bruhn, S., and Schaumann, G. E. (2017). "Physicochemical and microbial soil quality indicators as affected by the agricultural management system in strawberry cultivation using straw or black polyethylene mulching," Applied Soil Ecology 113, 36-44. DOI: 10.1016/j.apsoil.2017.01.014

Mwasha, A. (2009). "Using environmentally friendly geotextiles for soil reinforcement: A parametric study," Materials \& Design 30(5), 1798-1803. DOI:

10.1016/j.matdes.2008.07.018

Nagarajan, V., Mohanty, A. K., and Misra, M. (2013). "Sustainable green composites: Value addition to agricultural residues and perennial grasses," ACS Sustainable Chemistry \& Engineering 1(3), 325-333. DOI: 10.1021/sc300084z

Nair, K. P., Vivek, J. M., and Shibu, K. (2013). "Suitability of sludge as a building material," International Journal of Scientific \& Engineering Research 4(5), 21.

Nelson, P. N., Rhebergen, T., Berthelsen, S., Webb, M. J., Banabas, M., Oberthür, T., 
Donough, C. R., Indrasuara, K., and Lubis, A. (2011). "Soil acidification under oil palm: Rates and effects on yield," Better Crops 95(4), 22-25.

Ngo, T. P., Likitlersuang, S., and Takahashi, A. (2019). "Performance of a geosynthetic cementitious composite mat for stabilising sandy slopes," Geosynthetic International 26(3), 309-319. DOI:10.1680/jgein.19.00020

Nishino, T., Hirao, K., Kotera, M., Nakamae, K., and Inagaki, H. (2003). "Kenaf reinforced biodegradable composite," Composites Science and Technology 63(9), 1281-1286. DOI: 10.1016/s0266-3538(03)00099-x

Norul Izani, M. A., Paridah, M. T., Mohd Nor, M. Y., and Anwar, U. M. K. (2013). "Properties of medium-density fibreboard (MDF) made from treated empty fruit bunch of oil palm," Journal of Tropical Forest Science 25(2), 175-183.

Nurin, N. A, Abdul Khalil, H. P. S., Teh, W. F., Zafirah, N., Mohamad Haafiz, M. K., and Syakir, M. I. (2016). "Application of biodegradable material in restoring degraded soil system," International Journal of Environment, Society and Space 5(2), 18-26.

Oades, J. M. (1988). “The retention of organic matter in soils," Biogeochemistry 5, 3570. DOI: $10.1007 / \mathrm{BF} 02180317$

Ochi, S. (2008). "Mechanical properties of kenaf fibers and kenaf/PLA composites," Mechanics of Materials 40(4-5), 446-452. DOI: 10.1016/j.mechmat.2007.10.006

Oksman, K., Skrifvars, M., and Selin, J.-F. (2003). "Natural fibres as reinforcement in polylactic acid (PLA) composites," Composites Science and Technology 63(9), 13171324. DOI: 10.1016/s0266-3538(03)00103-9

Paridah, M. T., Basher, A. B., SaifulAzry, S. O. A., and Ahmed, Z. (2011). "Retting process of some bast plant fibres and its effect on fibre quality: A review," BioResources 6(4), 5260-5281.

Perrier, E. R. (1987). "An evaluation of soil-water management on an Alfisol in the semiarid tropics of Burkina Faso," in: Proceedings of the Consultants' Workshop on the State of the Art and Management Alternatives for Optimizing the Productivity of SAT Alfisols and Related Soils, Patancheru, India, pp. 59-65.

Ping, L. Y., Sung, C. T. B., Joo, G. K., and Moraidi, A. (2012). "Effects of four soil conservation methods on soil aggregate stability," Malaysian Journal of Soil Science 16(1), 43-56.

PORIM (1994). Environmental Impacts of Oil Palm Plantations in Malaysia, Palm Oil Research Institute of Malaysia, Kuala Lumpur, Malaysia.

Prabakar, J., and Sridhar, R. (2002). "Effect of random inclusion of sisal fibre on strength behaviour of soil," Construction and Building Materials 16(2), 123-131. DOI: 10.1016/s0950-0618(02)00008-9

Prats, S. A., Abrantes, J. R., Crema, I. P., Keizer, J. J., and Lima, J. L. M. P. (2017). "Runoff and soil erosion mitigation with sieved forest residue mulch strips under controlled laboratory conditions," Forest Ecology and Management 396, 102-112. DOI: 10.1016/j.foreco.2017.04.019

Pritchard, M. (1999). Vegetable Fibre Geotextiles, Unpublished Doctoral Thesis, University of Bolton, Bolton, England.

Por, S., Nishimura, S., and Likitlersuang, S. (2017). "Deformation characteristics and stress responses of cement-treated expansive clay under confined one-dimensional swelling," Applied Clay Sciences 146, 316-324 DOI:10.1016/j.clay.2017.06.022

Prodhan, Z. H. (2008). "Application of jute geotextile on rural roads of Bangladesh for slope protection," in: Proceedings of the International Workshop on Jute Geotextiles 
Technical Potential \& Commercial Prospects, Dhaka, Bangladesh.

Prosdocimi, M., Jordán, A., Tarolli, P., Keesstra, S., Novara, A., and Cerdà, A. (2016).

"The immediate effectiveness of barley straw mulch in reducing soil erodibility and surface runoff generation in Mediterranean vineyards," Science of The Total

Environment 547, 323-330. DOI: 10.1016/j.scitotenv.2015.12.076

Purohit, A., and Satapathy, A. (2017). "Mechanical and wear characteristics of epoxy composites filled with industrial wastes: A comparative study," IOP Conference Series: Materials Science and Engineering 178, Article ID 012019. DOI: 10.1088/1757-899x/178/1/012019

Rahman, S., Choudhury, J., and Ahmad, A. (2006). "Production of xylose from oil palm empty fruit bunch fiber using sulfuric acid," Biochemical Engineering Journal 30(1), 97-103. DOI: 10.1016/j.bej.2006.02.009

Ram, R., Shukla, J. P., Peters, E., Choudhary, S., and Prasad, K. (2009). “Application of geotextiles in erosion control: A field experiment," Journal of Arid Land Studies 19(1), 249-252.

Ramaswamy, G. N., Craft, S., and Wartelle, L. (1995). "Uniformity and softness of kenaf fibres for textile products," Textile Research Journal 65(12), 765-770. DOI: 10.1177/004051759506501210

Ramaswamy, G. N., and Easter, E. P. (1997). "Durability and aesthetic properties of kenaf/cotton blend fabrics," Textile Research Journal 67(11), 803-808. DOI: $10.1177 / 004051759706701104$

Rao, G. V. (2002). “Coir geotextiles strategic management initiatives,” in: Proceeding of International Coir Convention, Colombo, Sri Lanka.

Rickson, R. J. (2003). "The use of jute based products as geotextiles," in: Proceedings of the International Jute Symposium: Indian Jute-a New Symphony, Kolkata, India, pp. 161-175.

Rivas, T. (2006). Erosion Control Treatment Selection Guide, United States Department of Agriculture Forest Service National Technology \& Development Program, San Dimas, CA, USA.

Robichaud, P. R., Jordan, P., Lewis, S. A., Ashmun, L. E., Covert, S. A., and Brown, R. E. (2013). "Evaluating the effectiveness of wood shred and agricultural straw mulches as a treatment to reduce post-wildfire hillslope erosion in southern British Columbia, Canada," Geomorphology 197, 21-33. DOI:

10.1016/j.geomorph.2013.04.024

Robichaud, P. R., Rhee, H., and Lewis, S. A. (2014). "A synthesis of post-fire burned area reports from 1972 to 2009 for western US Forest Service lands: Trends in wildfire characteristics and post-fire stabilisation treatments and expenditures," International Journal of Wildland Fire 23(7), 929-944. DOI: 10.1071/wf13192

Romic, D., Romic, M., Borosic, J., and Poljak, M. (2003). "Mulching decreases nitrate leaching in bell pepper (Capsicum annuum L.) cultivation," Agricultural Water Management 60(2), 87-97. DOI: 10.1016/s0378-3774(02)00168-3

Ros, M., Garcia, C., and Hernandez, T. (2001). "The use of urban organic wastes in the control of erosion in a semiarid Mediterranean soil," Soil Use and Management 17(4),292-293. DOI: 10.1111/j.1475-2743.2001.tb00041.x

Rozman, H. D., Lai, C. Y., Ismail, H., and Ishak, Z. A. M. (2000). "The effect of coupling agents on the mechanical and physical properties of oil palm empty fruit bunch-polypropylene composites," Polymer International 49(11), 1273-1278. DOI: 10.1002/1097-0126(200011)49:11<1273::AID-PI469>3.0.CO;2-U 
Rowell, R. M. (1998). "Property enhanced natural fibre composite," in: Proceedings of the Fourth Pacific Rim Biobased Composites Symposium, Bogor, Indonesia, pp. 118.

Sahari, J., and Sapuan, S. M. (2011). "Natural fibre reinforced biodegradable polymer composites," Reviews on Advanced Materials Science 30(2), 166-174.

Sahat, S., Yusop, Z., Askari, M., and Ziegler, A. D. (2016). "Estimation of soil erosion rates in oil palm plantation with different land cover," IOP Conference Series: Materials Science and Engineering 136, Article ID 012086. DOI: 10.1088/1757899x/136/1/012086

Salilba, S. S., and Snide, J. A. (1990). "Fractography of composite materials," in: International Encyclopedia of Composites, Vol. 2, S. M. Lee (ed.), VCH Publishers, New York, NY, USA, pp. 268-289.

Samedani, B., Juraimi, A. S., Rafii, M. Y., Sheikh Awadz, S. A., Anwar, M. P., and Anuar, A. R. (2015). "Effect of cover crops on weed suppression in oil palm plantation," International Journal of Agriculture and Biology 17(2), 251-260.

Sanyal, T. (2008). "Prospective applications of jute geotextiles," in: Proceedings of the International Workshop on Jute Geotextiles Technical Potential \& Commercial Prospects, Dhaka, Bangladesh.

Sapuan, S. M., and Maleque, M. A. (2005). "Design and fabrication of natural woven fabric reinforced epoxy composite for household telephone stand," Materials \& Design 26(1), 65-71. DOI: 10.1016/j.matdes.2004.03.015

Satyanarayana, K. G., Ravikumar, K. K., Sukumaran, K., Mukherjee, P. S., Pillai, S. G. K., and Kulkarni, A. G. (1986). "Structure and properties of some vegetable fibres: Part 3 tailpot and palmyrah fibres," Journal of Materials Science 21(1), 57-63. DOI: 10.1007/BF01144699

Sellers, T., Miller, G. D., and Fuller, M. J. (1993). "Kenaf core as a board raw material," Forest Products Journal 43(7/8), 69-71.

Shainberg, I., Warrington, D. N., and Rengasamy, P. (1990). "Water quality and PAM interactions in reducing surface sealing," Soil Science 149, 301-307.

Shepherd, T. G., Saggar, S., Newman, R. H., Ross, C. W., and Dando, J. L. (2001). "Tillage induced changes to soil structure and organic carbon fraction in New Zealand soils," Australian Journal of Soil Research 39, 465-489. DOI: 10.1071/SR00018

Shen, H., Zheng, F., Wen, L., Lu, J., and Jiang, Y. (2015). "An experimental study of rill erosion and morphology," Geomorphology 231, 193-201. DOI: 10.1016/j.geomorph.2014.11.029

Shogren, R. (1992). "Effect of moisture content on the melting and subsequent physical aging of cornstarch," Carbohydrate Polymers 19(2), 83-90. DOI: 10.1016/01448617(92)90117-9

Shuaibu, R. A., Nyomboi, T., and Mutuku, R. N. (2015). "Shear strength of reinforced sugarcane bagasse ash-laterised concrete beams," Australian Journal of Structural Engineering 16(3), 199-207. DOI: 10.1080/13287982.2015.1092682

Singh, G., Manoharan, S., and Kanapathy, K. (1981). "Commercial scale bunch mulching of oil palms," in: Oil Palm in Agriculture in the Eighties, PORIM, Kuala Lumpur, Malaysia, pp. 367-377.

Singh, G., Kow, D. L., Lim, K. C., and Loong, S. G. (1999). "Empty fruit bunches as mulch," in: Oil Palm and the Environment: A Malaysian Perspective, G. Singh, K. H. Teo, and L. K. David (eds.), Oil Palm Growers' Council, Kuala Lumpur, Malaysia, 
pp. 171-183.

Singh, B., Gupta, M., and Tarannum, H. (2010). "Jute sandwich composite panels for building applications," Journal of Biobased Materials and Bioenergy 4(4), 397-407. DOI: $10.1166 /$ jbmb.2010.1110

Small, E., and Marcus, D. (2002). "Hemp: A new crop with new uses for North America," in: Trends in New Crops and New Uses, J. Janick, and A. Whipkey (eds.), ASHS Press, Alexandria, VA, USA., pp. 284-326.

Smith, H. J. C., Levy, G. J., and Shainberg, I. (1990). "Water-droplet energy and soil amendments: Effect on infiltration and erosion," Soil Science Society of America Journal 54(4), 1084-1087. DOI: 10.2136/sssaj1990.03615995005400040026x

Smith, G. D., Coughlan, K. J., Yule, D. F., Laryea, K. B., Srivastava, K. L., Thomas, N. P., and Cogle, A. L. (1992). "Soil management options to reduce runoff and erosion on a hardsetting Alfisol in the semi-arid tropics," Soil and Tillage Research 25(2-3), 195-215. DOI: 10.1016/0167-1987(92)90111-n

Smith, R. (2000). "The potential market for sisal and henequen geotextiles," in: Food and Agriculture Organization and Common Fund for Commodities, Proceedings of Seminar, Rome, Italy, Technical Paper (Vol. 14).

Smith, R. (2001). "The potential market for sisal and henequen geotextiles," in: Food and Agriculture Organization and Common Fund for Commodities. Proceedings of Seminar, Rome, Technical Paper (Vol. 14).

Snidjer, M. (2010). "NF Bioplastics to save coral reefs," Bioplastic Magazine 5, 34-35.

Son, J., Kim, H.-J., and Lee, P.-W. (2001). "Role of paper sludge particle size and extrusion temperature on performance of paper sludge-thermoplastic polymer composites," Journal of Applied Polymer Science 82(11), 2709-2718. DOI: 10.1002/app.2123

Sonthwal, V., and Sahni, D. (2015). "Subgrade soil improvement using jute fiber," International Journal of Emerging Technology and Advanced Engineering 5(6), 237240.

Sonthwal, V., and Sahni, D. (2015). "Subgrade soil improvement using jute fiber," International Journal of Emerging Technology and Advanced Engineering, June, 237-240.

Soykeabkaew, N., Supaphol, P., and Rujiravanit, R. (2004). "Preparation and characterization of jute- and flax-reinforced starch-based composite foams," Carbohydrate Polymers 58(1), 53-63. DOI: 10.1016/j.carbpol.2004.06.037

Stagnari, F., Galieni, A., Speca, S., Cafiero, G., and Pisante, M. (2014). "Effects of straw mulch on growth and yield of durum wheat during transition to conservation agriculture in Mediterranean environment," Field Crops Research 167, 51-63. DOI: 10.1016/j.fcr.2014.07.008

Di Stefano, C., Ferro, V., Pampalone, V., and Sanzone, F. (2013). "Field investigation of rill and ephemeral gully erosion in the Sparacia experimental area, South Italy," CATENA 101, 226-234. DOI: 10.1016/j.catena.2012.10.012

Sudiyani, Y., Styarini, D., Triwahyuni, E., Sudiyarmanto, S., Sembiring, K. C., Aristiawan, Y., Abimanyu, H., and Han, M. H. (2013). "Utilization of biomass waste empty fruit bunch fiber of palm oil for bioethanol production using pilot-scale unit," Energy Procedia 32, 31-38. DOI: 10.1016/j.egypro.2013.05.005

Sulaiman, O., Salim, N., Nordin, N. A., Hashim, R., Ibrahim, M., and Sato, M. (2012). "The potential of oil palm trunk biomass as an alternative source for compressed wood," BioResources 7(2), 2688-2706. 
Sumathi, S., Chai, S. P., and Mohamed, A. R. (2008). "Utilization of oil palm as a source of renewable energy in Malaysia," Renewable and Sustainable Energy Reviews 12(9), 2404-2421. DOI: 10.1016/j.rser.2007.06.006

Sutherland, R. A., and Ziegler, A. D. (2007). "Effectiveness of coir-based rolled erosion control systems in reducing sediment transport from hillslopes," Applied Geography 27(3-4), 150-164. DOI: 10.1016/j.apgeog.2007.07.011

Syakir, M. I., Nurin, N. A., Zafirah, N., Kassim, M. A., and Abdul Khalil, H. P. S. (2016). "Nanoclay reinforced on biodegradable polymer composites: Potential as a soil stabilizer," in: Nanoclay Reinforced Polymer Composites: Nanocomposites and Bionanocomposites (Engineering Materials), First Edition, M. Jawaid, A. E. K. Qaiss, and R. Bouhfid (eds.), Springer, Singapore, pp. 329-356.

Szott, L. (1987). Improving the Productivity of Shifting Cultivation in the Amazon Basin of Peru Through the Use of Leguminous Vegetation, Ph.D. Thesis, North Carolina State University, Raleigh, NC, USA.

Tanaka, R., Wan, R. W. D., Magara, K., Ikeda, T., and Hosoya, S. (2004). "Chlorine-free bleaching of kraft pulp from oil palm empty fruit bunches," Japan Agricultural Research Quarterly 38(4), 275-279. DOI: 10.6090/jarq.38.275

Tao, H.-H., Slade, E. M., Willis, K. J., Caliman, J-P., and Snaddon, J. L. (2016). "Effects of soil management practices on soil fauna feeding activity in an Indonesian oil palm plantation," Agriculture, Ecosystems \& Environment 218, 133-140. DOI: 10.1016/j.agee.2015.11.012

Tay, J.-H. (1987). “Bricks manufactured from sludge,” Journal of Environmental Engineering 113(2), 278-284. DOI: 10.1061/(asce)0733-9372(1987)113:2(278)

Teh, C. B. S., Joo, G. K., and Kamarudin, K. N. (2010). "Physical changes to oil palm empty fruit bunches (EFB) and EFB mat (ecomat) during their decomposition in the field," Pertanika Journal of Tropical Agricultural Science 33(1), 39-44.

Thambirajah, J. J., Zulkali, M. D., and Hashim, M. A. (1995). "Microbiological and biochemical changes during the composting of oil palm empty fruit bunches. Effect of nitrogen supplementation on the substrate," Bioresource Technology 52(2), 133144. DOI: 10.1016/0960-8524(95)00008-3

Thames, J. L. (1997). Sugar Cane Fiber Geotextiles, LSU Historical Dissertations and Theses, Louisiana State University, Baton Rouge, LA, USA.

Thomas, S., and Pothan, L. (2009). Natural Fibre Reinforced Polymer Composites from Macro to Nanoscale, Old City Publishing, Philadelphia, PA, USA.

Ticoalu, A., Aravinthan, T., and Cardona, F. (2010). "A review of current development innatural fiber composites for structural and infrastructure applications," in: Proceedings of the Southern Region Engineering Conference (SREC 2010), Toowoomba, Australia, pp. 113-117.

Tisdall, J. M., and Oades, J. M. (1982). "Organic matter and water-stable aggregates in soils," Journal of Soil Science 33(2), 141-163. DOI: 10.1111/j.13652389.1982.tb01755.x

Torres, F. G., Arroyo, O. H., and Gomez, C. (2007). "Processing and mechanical properties of natural fiber reinforced thermoplastic starch biocomposites," Journal of Thermoplastic Composite Materials 20(2), 207-223. DOI:

10.1177/0892705707073945

Toriz, G., Arvidsson, R., Westin, M., and Gatenholm, P. (2003). "Novel cellulose esterpoly(furfuryl alcohol)-flax fiber biocomposites," Journal of Applied Polymer Science 88(2), 337-345. DOI: 10.1002/app.11730 
Trivelin, P. C. O., Franco, H. C. J., Otto, R., Ferreira, D. A., Vitti, A. C., Fortes, C., Faroni, C. E., Oliveira, E. C. A., and Cantarella, H. (2013). "Impact of sugarcane trash on fertilizer requirements for São Paulo, Brazil," Scientia Agricola 70(5), 345 352. DOI: 10.1590/s0103-90162013000500009

Trout, T. J., Sojka, R. E., and Lentz, R. D. (1995). "Polyacrylamide effect on furrow erosion and infiltration," Transactions of the ASAE 38(3), 761-765. DOI: $10.13031 / 2013.27889$

Tserki, V., Matzinos, P., and Panayiotou, C. (2006). "Novel biodegradable composites based on treated lignocellulosic waste flour as filler. Part II. Development of biodegradable composites using treated and compatibilized waste flour," Composites Part A: Applied Science and Manufacturing 37(9), 1231-1238. DOI: 10.1016/j.compositesa.2005.09.004

Turner, P. D., and Gillbanks, R. A. (2003). Oil Palm Cultivation and Management, $2^{\text {nd }}$ Edition, Incorporated Society of Planters, Kuala Lumpur, Malaysia.

Vega, J. A., Fernández, C., and Fonturbel, T. (2005). "Throughfall, runoff and soil erosion after prescribed burning in gorse shrubland in Galicia (NW Spain)," Land Degradation \& Development 16(1), 37-51. DOI: 10.1002/ldr.643

Vega, J. A., Fernández, C., Fonturbel, T., González-Prieto, S., and Jiménez, E. (2014). "Testing the effects of straw mulching and herb seeding on soil erosion after fire in a gorse shrubland," Geoderma 223-225, 79-87. DOI: 10.1016/j.geoderma.2014.01.014

Vishnudas, S., Savenije, H. H. G., Van der Zaag, P., Anil, K. R., and Balan, K. (2008). "Participatory research using coir geotextiles in watershed management - A case study in south India," Physics and Chemistry of the Earth, Parts A/B/C 33(1-2), 4147. DOI: $10.1016 /$ j.pce.2007.04.016

Vishnudas, S., Savenije, H. H. G., Van der Zaag, P., and Anil, K. R. (2012). "Coir geotextile for slope stabilization and cultivation - A case study in a highland region of Kerala, South India," Physics and Chemistry of the Earth, Parts A/B/C 47-48, 135 138. DOI: $10.1016 /$ j.pce.2012.05.002

Wahab, H. A. (2001). "Forages in oil palm and rubber plantations in Malaysia," in: Forage development in Southeast Asia: Strategies and Impacts, Proceedings of the $7^{\text {th }}$ Meeting of the Regional Working Group on Grazing and Feed Resources, Manado, Indonesia.

Wambua, P., Ivens, J., and Verpoest, I. (2003). "Natural fibres: Can they replace glass in fibre reinforced plastics?," Composites Science and Technology 63(9), 1259-1264. DOI: 10.1016/s0266-3538(03)00096-4

Wagner, G. H., and Wolf, D. C. (1999). "Carbon transformations and soil organic matter formation," Principles and Applications of Soil Microbiology, Prentice Hall, Englewood Cliffs, NJ, USA, pp. 218-258.

Watson, G. A. (1989). "Field maintenance," in: Rubber, C. C. Webster (ed.), Longman Scientific, London, England, pp. 245-290.

Watson, C. A., Atkinson, D., Gosling, P., Jackson, L. R., and Rayns, F. W. (2002). "Managing soil fertility in organic farming systems," Soil Use and Management 18, 239-247.

Webber, C. L., III, and Bledsoe, R. E. (1993). "Kenaf: Production, harvesting, processing, and products," in: New Crops, J. Janick, and J. E. Simon (eds.), Wiley, New York, NY, USA, pp. 416-421.

Webber, C. L., III, Bhardwaj, H. L., and Bledsoe, V. K. (2002). "Kenaf production: Fiber, feed, and seed," in: Trends in New Crops and New Uses, J. Janick, and A. 
Whipkey (eds.), ASHS Press, Alexandria, VA, USA, pp. 327-339.

Wollerdorfer, M., and Bader, H. (1998). "Influence of natural fibres on the mechanical properties of biodegradable polymers," Industrial Crops and Products 8(2), 105-112. DOI: $10.1016 / \mathrm{s} 0926-6690(97) 10015-2$

Yadav, J. S., and Tiwari, S. K. (2016). "Behaviour of cement stabilized treated coir fibrereinforced clay-pond ash mixtures," Journal of Building Engineering 8, 131-140. DOI: $10.1016 /$ j.jobe.2016.10.006

Yin, W. S., Li, J., and Li, Y. M. (1997). "Conducting IPN based on polyaniline and crosslinked cellulose," Polymer International 42(3), 276-280. DOI: 10.1002/(SICI)1097-0126(199703)42:3<276::AID-PI718>3.0.CO;2-F

Yonavjak, L. (2013). "Industrial hemp: A win-win for the economy and the environment," Forbes, (https://www.forbes.com/sites/ashoka/2013/05/29/industrialhemp-a-win-win-for-the-economy-and-the-environment/\#74e21bf2289b), Accessed 04 June 2017.

Zachar, D. (1982). Soil Erosion, Elsevier Scientific, Amsterdam, Netherlands.

Zafirah, N., Shaiful, Y., Nurin, N. A., Widad, F., and Syakir, M. I. (2016). "Role of ecosystem services in catchment management: A snapshot," International Journal of Environment, Society and Space 5(2), 42-50.

Zaidi, A., Khan, M. K., Khan, Z. R., and Husain, S. M. A. (2016). "Enhancement in engineering properties of soil reinforced with jute fiber," International Journal of Emerging Technologies in Engineering Research (IJETER) 4(4), 96-98.

Zaidon, A., Norhairul Nizam, A. M., Faizah, A., Paridah, M. T., Jalaluddin, H., Mohd Nor, M. Y., and Nor Yuziah, M. Y. (2008). "Efficacy of pyrethroid and boron preservatives in protecting particleboards against fungus and termite," Journal of Tropical Forest Science 20(1), 57-65.

Zainudin, E. S., Sapuan, S. M., Abdan, K., and Mohamad, M. T. M. (2009). "Dynamic mechanical behaviour of banana-pseudostem-filled unplasticised polyvinyl chloride composites," Polymer and Polymer Composites 17(1), 55-61.

Zampaloni, M., Pourboghrat, F., Yankovich, S. A., Rodgers, B. N., Moore, J., Drzal, L. T., Mohanty, A. K., and Misra, M. (2007). "Kenaf natural fiber reinforced polypropylene composites: A discussion on manufacturing problems and solutions," Composites Part A: Applied Science and Manufacturing 38(6), 1569-1580. DOI: 10.1016/j.compositesa.2007.01.001

Ziegler, A. D., Sutherland, R. A., and Giambelluca, T. W. (2001). “Acceleration of Horton overland flow and erosion by footpaths in an upland agricultural watershed in northern Thailand," Geomorphology 41(4), 249-262. DOI: 10.1016/S0169$555 X(01) 00054-X$

Article submitted: July 9, 2020; Peer review completed: January 26, 2021; Revised version received and accepted: March 12, 2021; Published: March 30, 2021.

DOI: 10.15376/biores.16.2.Syakir 